\title{
Communicating in Good Faith? Dynamics of the Christian Right Agenda
}

DOI:

$10.1017 / \mathrm{S} 1755048319000543$

\section{Document Version}

Accepted author manuscript

Link to publication record in Manchester Research Explorer

\section{Citation for published version (APA):}

Wilson, A., \& Djupe, P. (2020). Communicating in Good Faith? Dynamics of the Christian Right Agenda. Politics and Religion, 13(2), 385-414. https://doi.org/10.1017/S1755048319000543

\section{Published in:}

Politics and Religion

\section{Citing this paper}

Please note that where the full-text provided on Manchester Research Explorer is the Author Accepted Manuscript or Proof version this may differ from the final Published version. If citing, it is advised that you check and use the publisher's definitive version.

\section{General rights}

Copyright and moral rights for the publications made accessible in the Research Explorer are retained by the authors and/or other copyright owners and it is a condition of accessing publications that users recognise and abide by the legal requirements associated with these rights.

\section{Takedown policy}

If you believe that this document breaches copyright please refer to the University of Manchester's Takedown Procedures [http://man.ac.uk/04Y6Bo] or contact uml.scholarlycommunications@manchester.ac.uk providing relevant details, so we can investigate your claim.

\section{OPEN ACCESS}




\section{Politics and Religion \\ Communicating in Good Faith? Dynamics of the Christian Right Agenda --Manuscript Draft--}

\begin{tabular}{|c|c|}
\hline Manuscript Number: & PRJ-D-19-00080R2 \\
\hline Full Title: & Communicating in Good Faith? Dynamics of the Christian Right Agenda \\
\hline Article Type: & Article \\
\hline Keywords: & $\begin{array}{l}\text { Christian Right; Family Research Council; political communication; lobbying; press } \\
\text { releases }\end{array}$ \\
\hline Corresponding Author: & $\begin{array}{l}\text { Paul A. Djupe, PHD } \\
\text { Denison University } \\
\text { Worthington, OH UNITED STATES }\end{array}$ \\
\hline \multicolumn{2}{|l|}{$\begin{array}{l}\text { Corresponding Author Secondary } \\
\text { Information: }\end{array}$} \\
\hline Corresponding Author's Institution: & Denison University \\
\hline \multicolumn{2}{|l|}{$\begin{array}{l}\text { Corresponding Author's Secondary } \\
\text { Institution: }\end{array}$} \\
\hline First Author: & Angelia Wilson, PhD \\
\hline \multicolumn{2}{|l|}{ First Author Secondary Information: } \\
\hline \multirow[t]{2}{*}{ Order of Authors: } & Angelia Wilson, PhD \\
\hline & Paul A. Djupe, PHD \\
\hline \multicolumn{2}{|c|}{ Order of Authors Secondary Information: } \\
\hline Manuscript Region of Origin: & UNITED STATES \\
\hline Abstract: & $\begin{array}{l}\text { It is an article of faith that organized interests represent members to elected officials } \\
\text { making use of synchronized communication channels. Rarely, have researchers had } \\
\text { access to multiple, internal and external channels to test this notion. We mine a trove } \\
\text { of nearly } 2,500 \text { emails the Family Research Council (FRC) sent to list subscribers from } \\
2007 \text { to } 2018 \text {. Text tools allow us to depict message flexibility of the FRC and how } \\
\text { internal (email) and external (press release) messages may be linked. Finally, we note } \\
\text { the bills lobbied by FRC and the frequency these are mentioned in the internal email } \\
\text { messages. Our findings show that different audiences are presented with considerably } \\
\text { different political agendas in ways that appear to conform to the requisites of the } \\
\text { different audiences. While FRC has significant, sophisticated message flexibility, our } \\
\text { analysis indicates that such flexibility can raise serious concerns about good faith } \\
\text { representation. }\end{array}$ \\
\hline \multirow[t]{2}{*}{ Suggested Reviewers: } & $\begin{array}{l}\text { Katherine Knutson } \\
\text { Gustavus Adolphus College } \\
\text { knutson@gustavus.edu } \\
\text { She has published on religious interest group communication before }\end{array}$ \\
\hline & $\begin{array}{l}\text { Clyde Wilcox } \\
\text { Georgetown University } \\
\text { wilcoxc@georgetown.edu } \\
\text { Obviously a CR scholar of renown. }\end{array}$ \\
\hline \multirow[t]{2}{*}{ Opposed Reviewers: } & $\begin{array}{l}\text { Tobin Grant } \\
\text { SIU-C } \\
\text { I mean, of course. }\end{array}$ \\
\hline & $\begin{array}{l}\text { Dan Olson } \\
\text { Purdue } \\
\text { Demonstrated inability to be objective. }\end{array}$ \\
\hline
\end{tabular}


Response to Reviewers:

Additional Information:

Question

Manuscript Classifications:
Thanks so much for shepherding this toward publication!

Best,

Paul and Angie

\section{Response}

150.400: Political Parties and Organizations; 162: Religion and Politics 


\title{
Communicating in Good Faith? Dynamics of the Christian Right Agenda
}

\author{
Angelia R. Wilson \\ Department of Politics \\ University of Manchester \\ Manchester, UK \\ angelia.r.wilson@manchester.ac.uk
}

\author{
\& Paul A. Djupe \\ Department of Political Science \\ Denison University \\ Granville, Ohio 43023 \\ djupe@denison.edu
}

\begin{abstract}
It is an article of faith that organized interests represent members to elected officials making use of synchronized communication channels. Rarely, if at all, have researchers had access to multiple, internal and external channels to test this notion. We mine a trove of nearly 2,500 emails the Family Research Council (FRC) sent to list subscribers from 2007 to 2018. Text tools allow us to depict message flexibility of the FRC. We then consider how internal and external messages may be linked by examining the issue content of emails in relation to press releases. Finally we note the bills lobbied by FRC and the frequency these are mentioned in the internal email messages. Our findings are twofold. First, they support the conditional independence of communication channels in ways that appear to conform to the requisites of the different audiences: elected officials are likely mobilized by different signals than members are. Second, our evidence shows that the flexibility organized interests have in composing their communications can mean that different audiences are presented with considerably different political agendas. While FRC has significant sophisticated message flexibility, our data set indicates that such flexibility can raise serious concerns about good faith representation.
\end{abstract}

Final Submission Politics \& Religion August 22, 2019

\section{Acknowledgements}

We wish to thank Tony Nownes, Steven Kettell, Rachel Gibson, Ken Wald, Andrea Hatcher, and David Buckley for their helpful feedback on earlier versions of this paper, in addition to our thanks to the guest editor Bethany Albertson and the two anonymous reviewers for their help in honing the arguments and presentation. 


\section{Communicating in Good Faith? Dynamics of the Christian Right Agenda}

It is an article of faith that organized interests represent members to elected officials through synchronized communication channels. In doing so, their communications need to be flexible in order to adapt to evolving policy issues, audiences, and conditions. This flexible, strategic messaging is thought to compliment their representative role, as effective framing captures the media's attention and augments citizen investment in issue campaigns. Until now, the scholarly community has relied largely upon external messaging (e.g., press releases) to document strategic flexibility. Our research is among the first to systematically compare internal, or ingroup, messaging to more familiar external communications and focuses not on framing, but the rudiments of representation - the agenda. The outcome raises questions about the relationship between strategic messaging and the representative role played by interest groups. Are the various communication channels that groups operate conveying the same working agenda?

Our evidence, taken from nearly 2,500 emails sent from the Family Research Council (FRC) to their constituents over a ten-year period, 603 of their press releases from a five-year period, and lobbying reports submitted to the Clerk of Congress across this time span, demonstrates that organizations can be flexible in their rhetoric, crafting messages separately to ingroup and external audiences, and presenting, for the most part, independent agendas to these audiences. We then attempt to account for this pattern, looking to parse whether organizational elites are strategic and mark unconstrained flexibility or whether they follow a pattern constrained by the needs of the audience of a particular channel. While much of the evidence is agnostic on this point, we are able to draw on the intervention of the Supreme Court in Obergefell vs. Hodges (2015), which radically changed the political environment for the FRC and the meaning of signals sent by taking up the anti-gay rights cause. Our analysis of internal and external communications confirms a sophisticated level of agenda flexibility, but it also raises questions about the potential for agenda flexibility to undermine good faith representation. 


\section{Dynamics of Flexibility}

To study organized interests is at least implicitly to study communication. Often that is the prosaic communication of interest to Members of Congress to vote yes or no, but there are several other dimensions to messaging involving, for example, who says what, when, how, and to whom. That communication of an agenda, what steps are to be taken, and what those steps mean is the critical work in defining just what an interest is. It is what links people and their resources to political goals (e.g., Snow et al. 1986). It helps government officials envision the scope of the problem and link it to both principles and constituents. For example, the primary function of rhetoric or the framing of an issue is to manipulate "the public vocabulary to bring about social change" (Andsager 2000: 578). Successful interest group politics depends on a group's ability to define "an issue over time" and to adapt "those definitions to fit the changing political and social climate" (Terkildsen et al. 1998: 46). It almost goes without saying that adept coordination and deployment of rhetoric shapes activists' ability to inspire and motivate support (e.g., Chong and Druckman 2008; though see Jerit 2008).

It is important, if obvious, to point out that communication serves many masters. Organized agents are simultaneously trying to maintain relationships with coalition partners (Leifeld and Schneider 2012) and government officials (Bauer, Poole, and Dexter 1963; McCrain forthcoming; Nownes 1999; Victor and Koger 2016), recruit and meet the expectations of members (Gray and Lowery 1996; Salisbury 1969), and adopt novel arguments that will influence the mass media (e.g., Andsager 2000; Terkildsen et al. 1998). In addition, the external messages must be palatable and translatable to a wider public. It makes sense that a significant amount of research on interest group rhetoric focuses on two aspects of the relationship between interest groups and the media: the extent to which the media appropriates a group's rhetoric in framing an issue for wider public consumption and the effectiveness of that framing on policy outcomes (Andsager 2000; Baumgartner, Linn and Boydstun 2009; Knutson 2011; Rose and Baumgartner 2013; Terkildsen et al., 1998). Studies attest to the difficult balancing act of maintaining these 
relationships while constrained by conflicting goals, for example, where gaining access to public officials stands in contradistinction to mobilizing the public (e.g., Dür and Mateo 2013), or maintaining membership is a primary consideration above gaining access to public officials (Gray and Lowery 1996; Nownes 1999).

However, documenting the competing pressures from multiple audiences has been inhibited since most interest group research on group communication has relied upon publicly available lobbying reports, press releases, media coverage, or public hearings (e.g., Ray 2018; though see Godwin's [1988] use of direct mail). By its nature this data comes from externalfacing narratives attempting to frame an issue for policy makers and the media. Therefore, much of this research has had to assume that, for instance, press releases are representative of the communication the group would provide in "all directions" (Browne 1998). For example, Knutson (2011: 313, citing Andrews and Edwards 2004) argues that groups strategically choose external frames that would appeal to both members and policymakers. Lobbyists, by and large, are conceived as representing interests with "perfect fidelity" (Lowery and Marchetti 2012: 140).

Lowery and Marchetti (2012) raise important concerns about this very assumption, arguing interest groups are likely rife with principal-agent problems, in part, because "control systems are weak" (141) and interest sets are complex making outcomes ambiguous (Godwin, Godwin, and Ainsworth 2007). Concluding that "renewed attention must be paid to the internal operation of interest organizations," Lowery and Marchetti express guarded optimism that the "severity of agency problems might well be minimized via the internal decisions of interest organizations" (2012: 165).

However, research has not been able to address the dynamics of interest group internal messaging. There is very little evidence about how internal interest group communication may shift over time, in relation to the wider political agenda, or, most importantly, in relation to the organization's other messaging. For example, in their book Democracy for Realists, Christopher Achen and Larry Bartels point out that "we need to know more about how interest groups 
acquire their clout" (2017: 322). They astutely posit that an interest group's ability to influence members to vote in certain ways probably makes politicians listen to their proposals. Evidence about how, exactly, they do that is "exceedingly rare" and "uncomfortably thin" (Achen and Bartels 2017: 322). While this may be an overstatement (see, e.g., Baumgartner, Berry, et al. 2009; Godwin 1988; McFarland 1984), just how the relationships between the organization, members, and government officials fit together to move interests forward has advanced but is still less than fully understood.

There are only hints in existing research that organizations may focus on quite different portions of their agenda to different constituencies at any one time. We believe the critical neopluralist insight is that groups have varied constituencies that force contingent operation (Heinz et al. 1993; Gray and Lowery 1996; Lowery and Brasher 2004). Communication to members needs to articulate a common set of threatened interests, effectively signaling the need for group advocacy. There are many ways to do this effectively that have been documented across expansive literatures across many disciplines. We can look for the value of outlining a threat (e.g., Davis and Silver 2004; Huddy et al. 2005; Loomis and Cigler 2007: 22; Miller and Krosnick 2004; Moe 1980; Sullivan, Piereson, and Marcus 1982), identifying an outgroup (e.g., Tajfel 1970), posing a beleaguered minority status (e.g., Smith 1998), drawing out anxiety, fear, and anger (e.g., Brader 2006; Brader and Marcus 2013; Godwin 1988), and generally highlighting the potential for loss (Kahneman and Tversky 1979).

Alternatively, when working with government officials, organized interests tend to mobilize bias in government in the hopes of deploying advocates to work on their behalf (e.g., Hall and Wayman 1990; Hojnacki and Kimball 1998). It makes sense, then, that government officials rely on groups as service providers (Bauer, Poole, and Dexter 1963; Leifeld and Schneider 2012), and access to officials spreads along with resources. Powerful groups lobby more broadly (Hojnacki and Kimball 1998), and officials are willing to grant meetings to individuals from dominant groups (e.g., Carnes and Holbein nd; Kalla, Rosenbluth, and Teele 
2017). Therefore, if communication is used to help maintain relationships with officials and bolster the importance of their voice, the group would not signal minority status, fear, and threat, but majority status, confidence, expertise, agreement, and promise.

Our research suggests that in an effort to navigate these complex waters of communication strategy, interest group elites do not or cannot always act as a transparent link, simple amplifier, or "superconducting transmitter" (Lowery and Marchetti 2012: 140) of members' concerns to policy makers. Therefore, the need for strategic messaging sits uneasily with what one might understand to be at the heart of interest group communication representation of members" interests. If "the success of lobbyists depends on their ability to act as a communication link between the government and the group's membership" (Ainsworth and Sened 1993), then at some point the flexibility needed to adapt to political events and differentially communicate to internal and external audiences begins to raise concerns about claims to representation.

We already had such concerns generated by the Olsonian theory of joining based on selective incentives (Olson 1965), which highlighted the potential disconnect between members and leadership. Joining and retention decisions could be based on considerations alternate to policy representation (though see, e.g., Rothenberg 1989). There is some evidence of this in our data, as FRC emails occasionally offer discounts on publications, event tickets, or vacation tours. Therefore, it is an open question whether leaders' external statements, lobbying members of Congress for example, are actually representing all members' political interests.

But even if members do join on the basis of resonant political position-taking, democratic dilemmas remain in this principal-agent relationship when viewed from a communication perspective. In modern atomistic membership groups (Putnam 2000; Skocpol 2004), leaders/entrepreneurs are providing policy (purposive) benefits that effectively only they can communicate. Organizational leaders communicate which issues are important, what positions they take, what they did, and what effect their actions had. It is entirely possible, even 
quite likely, that this feedback loop is oftentimes incomplete or even misinformed (Lowery and Marchetti 2012). In fact, existing works find that not all organized interests "go public" (Hofrenning 1995; Kollman 1998; Nownes and Freeman 1998; Schlozman and Tierney 1983), but we have no data on the extent to which groups use techniques to inform and influence the public (except in the sense of social media use - see, e.g., Chalmers and Shotton 2016). And the measures we have from survey data are surely generous to the organization since they are, after all, self-reported. It is a fair assumption that organizations do not tell their members all of what they do. Indeed, our findings will suggest that the group under study does not always tell members about political interventions made on their behalf. Finding discordant agendas presented internally and externally raises serious concerns about representation.

This discussion draws out two competing hypotheses. First, if groups engage in 360 degree communication, then there will be no divergence between communication channels. This follows the classic interest group assumption, that group is interest and interest is group (Bentley 1995[1908]). However, we expect to reject the first hypothesis, which leads to a second. If their communication channels diverge in agendas, the reason for that divergence follows the needs of the audience: groups will emphasize issue agendas to members that highlight threat, while they will emphasize issue agendas to the media and elected representatives that convey strength.

Though clearly speculative at this point, it is worth reflecting briefly on the conditions that might encourage convergence of agendas. Perhaps the right analogy is thinking about why closely-related organizations band together despite segmented constituencies. For instance, likeminded groups collaborate on the same agenda when facing a powerful foe (Gray and Lowery 1998; see also Hojnacki 1997). We suspect that any such policy threat, whether due to the power of the foe or resource deficit of the organization, would encourage a unified response. We would also expect that periods of flux - when equilibria are punctuated and statuses are insecure would serve as an equivalent force on organizational agendas (e.g., Baumgartner and Jones 1993).

\section{Religious Interest Groups and Flexible Messaging}


Before turning to our data, it is important to address the argument that religious interest groups may be less inclined towards flexibility because they are constrained by their own theologically rigid or moral framework (Hofrenning 1995; Knutson 2013; Rohlinger 2002). The internal diversity of religious groups can constrain organizational leaders as they construct communication. Clergy, for instance, are pinched between political differences within a congregation or between a congregation and denominational doctrine (Calfano 2010; Hadden 1969; Neiheisel and Djupe 2008), and denominational lobbies keep at arm’s length “bleeding edge" issues - any that do not enjoy widespread support in the denomination (see, e.g., Olson 2002). Moreover, as the denominational lobbies continue to shrink along with their denominations, coalition advocacy has become much more common and religious lobbies have joined secular groups to form issue advocacy coalitions, such as Interfaith Power and Light and others. This opens up coalitions to the intricacies of pleasing members from different faith traditions that can make generating statements "difficult, time consuming, and slow" (Knutson 2013: 121). Nevertheless, the history of the Christian Right demonstrates a willingness to compromise in order to work with similarly motivated religious groups and to navigate changing political currents (Moen 1994; Wilcox 1994; Shields 2009; Williams 2012).

Knutson (2011) challenges the notion that religious interest groups are "unable or unwilling" to compromise on rhetoric due to moral rigidity. Her study of the language in press releases demonstrates that religious lobbying groups reflect an approach to political strategy and sophistication consistent with non-religious groups. Religious groups operate strategically in high-profile debates "issuing a variety of arguments, many of those not based on morality, in hopes of influencing policy outcomes" (2011: 332). This echoes a range of other evidence that religious groups, particularly the Christian Right, which are decidedly not denominational lobbies, are sophisticated political actors with "pragmatic strategies" (Rozell and Wilcox 1996; Wilson and Burack 2012; Smith 2014; Moen, 1994; Calfano and Djupe 2009; Campbell and Monson 2008; Green, Rozell and Wilcox 2006). Therefore, current research indicates that like 
secular interest groups, religious interest groups can have significant flexibility in messaging across different channels.

\section{Data}

The data for several communication channels comes from the Family Research Council (FRC). Founded originally in the early 1980s by James Dobson as part of his Focus on the Family organization, the Family Research Council stands now as an independent charity and activist group. The lobbying arm is FRCAction. According to their homepage, the FRC vision is "a culture in which all human life is valued, families flourish, and religious liberty thrives." This vision is most often expressed in shorthand as "faith, family and freedom" or increasingly as "life, family and liberty." FRC has over 120 staff, including policy experts and digital strategists, with an operating budget of around $\$ 16$ million. FRCAction has an additional budget of around $\$ 2.3$ million. Tony Perkins, President since 2003, has transformed the organization into a financially secure machine of social conservative policy creation and advocacy.

From the beginning, FRC was well-connected in DC through its first two presidents, Jerry Regier and Gary Bauer, who served in the Reagan administration. FRC continues to be well connected and is arguably now the most powerful Christian Right political organization in America. GOP Senate Leader Mitch McConnell recently appointed Perkins as a US Commissioner on International Religious Freedom. Substantial financial supporters of FRC are the Michigan-based Prince and DeVos families. Betsy (Prince) DeVos has been a longtime friend of FRC and, under the Trump administration, has become the U.S. Secretary of Education.

The data available to test these claims results from a decision the lead author made in 2007 to subscribe to the email list of the FRC. Emails steadily accreted from December, 2007 to mid-2018 to yield a treasure trove of 2,463 emails. They did not arrive in a perfectly steady stream, but varied somewhat from month to month (as shown in Figure A1 in the Supplemental 
Information Appendix). In a peak month, the FRC sent out nearly 80 emails (e.g., January 2008), while 2011 and 2016 are quite sparsely populated. ${ }^{1}$

It is common for studies of interest group communication to study one communication channel, but our narrative requires examining content from multiple channels at the same time. We are fortunate that the FRC provides an archive of their press releases on their website dating back five years, which we scraped into a dataframe of 603 documents covering 2013 to January 2018. It is impossible for us to tell at this point if this archive is comprehensive or not, though we assume it is.

We engage one further data source. The FRC employs registered lobbyists and must file reports with Congress documenting their lobbying efforts, which exist online from 1999 to 2018. ${ }^{2}$ Starting in the $110^{\text {th }}$ Congress, FRC reported lobbying on nearly 850 bills, though most of them were duplicates across quarters and often across congresses as bills were reintroduced. For the purposes of searching FRC communications for bill mentions we stripped off years (e.g., Stop Enabling Sex Traffickers Act 2017) and searched for shortened 288 “unique” legislative titles. $^{3}$

With the email and press release data, we began by tokenizing the data into discrete words using the tidytext package in R (Silge and Robinson 2016). We stripped out "stop words," such as conjunctions and "the" among many others; the emails also contain a variety of html

\footnotetext{
${ }^{1}$ It is not clear why those years have so few emails - it may have been a temporary policy change, an inbox problem, or something else.

${ }^{2}$ For instance, here: https://soprweb.senate.gov/index.cfm?event=selectfields

${ }^{3}$ Lobbying reports include short, (less than fully) descriptive reasons for lobbying on particular pieces of legislation that we are working on coding for future work that can mesh with FRC's communication stream. For instance, the explanatory text for their lobbying on S1241, the Child Interstate Abortion Notification Act, suggests, "Provides parental notice for minors seeking abortion." Many other explanatory texts are less forthcoming. In the hopes of gaining useful issue coding, we matched all bills mentioned with Policy Agenda Project codes. Those codes are not as fine grained as we hoped and do not attach to the main issues of concern for the FRC - not nearly all bills concerned with abortion gain an abortion-related code. However, this quick analysis does highlight the diversity of general policy contexts in which FRC finds issues of concern - see Figure A3 in the Appendix. It seems clear they would spend quite a bit of time hovering around the Judiciary committee given the concentration of "civil rights" issues, which also attracts participants catering to culture wars constituencies (Lewis 2014).
} 
tags that were cleaned out as well. This process leaves us with 1.09 million words for analysis that are linked to their original source email and date in the dataframe.

We aggregate our data to months, providing a maximum of 117 months covering the full set of emails. While date concentrations are arbitrary, months help smooth agendas over what may be jittery issues in emails and press releases. ${ }^{4}$ We focus our attention on 4 key policy areas that the FRC engaged across this time period: abortion, marriage, liberty, and LGBT rights.

We focus on the agenda, in which a policy issue (sometimes shortened to 'issue') can be considered on an agenda when the organization is acting on it in some way, including engaging in policy debates. Naturally our research question concerns whether there is a singular agenda or multiple agendas. Policy debates are composed of one or more frames, which may be in competition. We focus on the agenda as our data collection effort attempts to aggregate frames by including the wide variety of terms used in each policy debate. It is a different and important question that remains for future research whether organizations employ different specific frames to different constituencies simultaneously.

Each policy issue agenda space is constructed from the verbiage used by the FRC in combination with well-known word connotations. So, to capture their agenda involving abortion, for instance, we collected mentions of abort, abortion, abortionist, abortions, fetus, baby, babies, unborn, pain-capable, and infanticide. It turns out that a simple definition using versions of abort* has almost a perfect correlation $(\mathrm{r}=.98)$ with the agenda space captured by a more complex version at the month level (see Figure A4). The FRC has adopted some of the more creative labels from the pro-life lobby like "pain-capable," but this term is clearly used in conjunction with the more commonly used abort* terms.

The banners from the earliest FRC emails articulate their values as "Faith, Family \& Freedom," which are reflected consistently in their most recent website headings of "Life,

\footnotetext{
${ }^{4}$ We also repeated the analyses aggregating the data to quarters and found similar results.
} 
Family, \& Liberty.” These core values underpin what we believe to be key political issues: abortion, homosexuality, marriage, and liberty. These themes have been identified by scholars working in the field of religion and politics to be of particular political concern to the Christian Right (e.g., Wilcox and Robinson 2010).

We have two goals for examining our data. First, it is worth documenting what the FRC's agenda looked like over time. Therefore, we begin by describing the outcome of tracking each agenda theme over time in the emails and press releases, documenting what is happening when rhetoric spikes. Second, we test whether internal (email) rhetoric tracks the external (press release) rhetoric. We also search for mentions of specific lobbying activity by looking for bills mentioned in emails. This analysis highlights the degree to which efforts to manage relations with office-holders are reflected in communication designed to manage relations with supporters.

\section{Depiction of Internal and External Agenda Communication}

In this section we consider the frequency of the appearance in the two major communication channels of four themes: abortion, homosexuality, marriage, and liberty. The data demonstrate the responsiveness of internal messaging. In describing the ebb and flow of each theme, we note the correspondence of the political environment with particular spikes in the themes. It is not clear if the FRC deployment of these themes at particular times is proactive or reactive, simply that the themes in emails correlate with events in the wider political environment. Figure 1 shows the distribution of issue communication in emails across time, while Figure 2 shows the press release data. We have three alternate views available in the appendix - email communication highlighting one issue at a time appears in Figures A5, Figure A6 shows press release communication with one issue highlighted, and Figure A7 shows email and press release communication by issue over time.

\section{Abortion}


Abortion is arguably the leading issue that motivates Christian Right voters, and at least underlies CR agenda activity (Lewis 2017). The Family Research Council represents the long tradition of anti-abortion perspectives that have been affiliated with the Christian Right since a few years lag after the US Supreme Court decision in Roe $v$. Wade (1973). Figure 1 tracks the number of times abortion-related terms (described above) appear in emails by month. ${ }^{5}$ Given the centrality of abortion to the FRC, one might assume that this issue would have a regular appearance in emails. However, the frequency of abortion rhetoric is sporadic, though never missing. In the years 2008-2011 there are months in which abortion tops the agenda. These spikes map onto the wider political context, indicating that abortion appears more frequently at times of either US presidential or mid-term Congressional elections. The only other clear spike during this period is during mid-2009 when Congress and society debated Obamacare.

Interestingly, abortion appears less frequently in emails directed to constituents during Obama’s second term in office (2012 - 2016). However, by the 2016 general election abortion reappears in significant concentrations. The most recent spike in the abortion rhetoric is in early 2018. This seems to reflect the events marking 45 years since the Roe $v$. Wade decision on January 22, 1973. For example, FRC emails around this time promoted "Sanctity of Life Sunday" on January $21^{\text {st }}$, supplying local congregations with bulletin inserts explaining their biblical theology on the issue and encouraging individuals to pray, "affirm President Trump for appointing prolife justices," "contact your representative and senators", "educate yourself on pro-life arguments," and "support a pregnancy care center in your area."

\footnotetext{
${ }^{5}$ Another version of this figure shown with one issue highlighted at a time appears in Appendix Figure A5.
} 


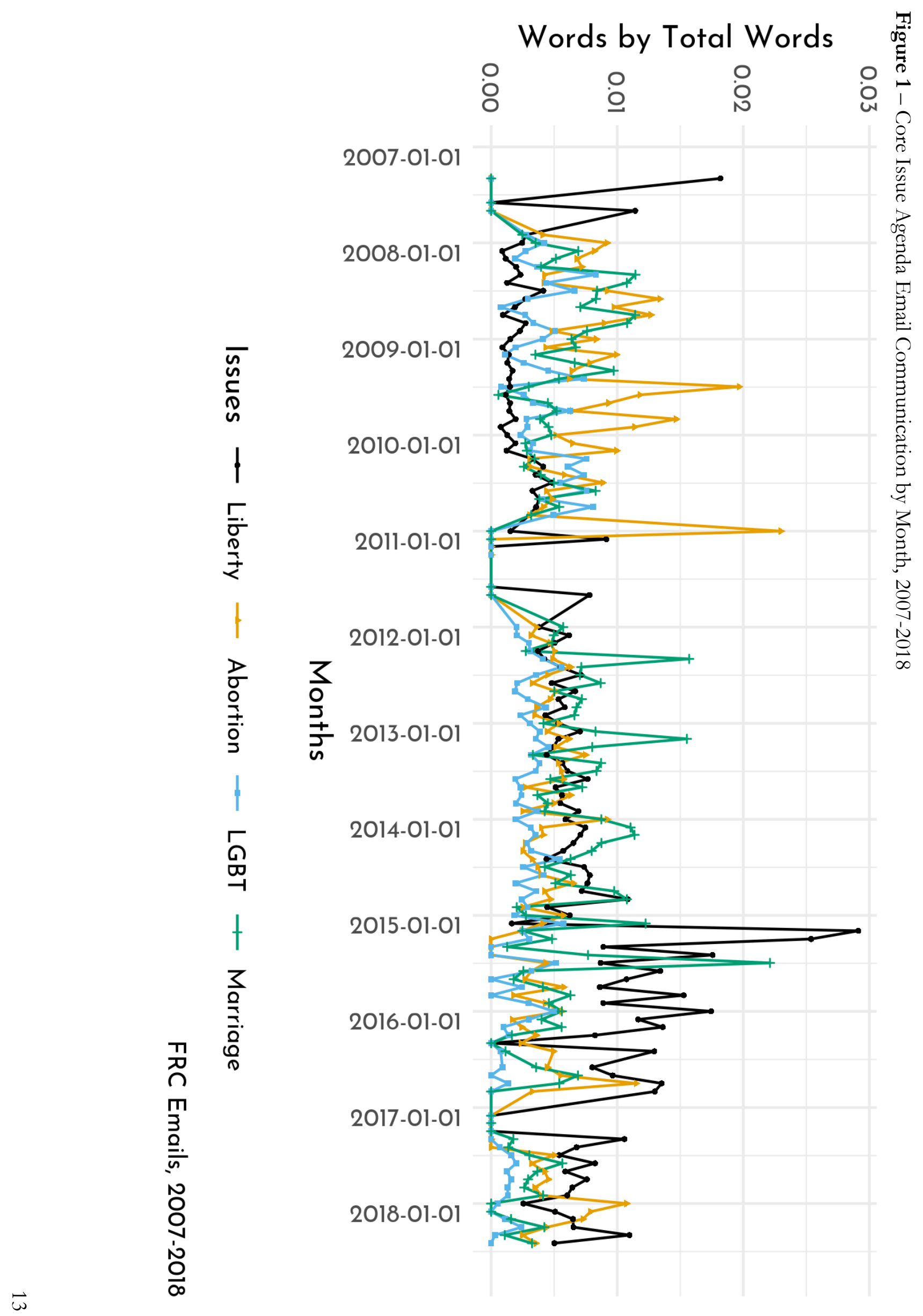


Given its centrality to the FRC organizational aims, one might expect to see abortion rhetoric appear more consistently in constituent emails. However, the spikes appear at times of potential loss - elections and pending policy change. This may indicate that abortion rhetoric fits a script that should be particularly useful for maintaining support through emphasizing fear of loss and minority status that demands action.

Figure 2 shows abortion's place on the external, press release agenda and presents what appears to be a quite different story. While it does not cover the same extensive time period as the emails, the press releases show a spike at the beginning of each year (the Roe anniversary), but then much more intense focus on abortion in the last several years. As marriage drops off their external agenda after Obergefell $v$. Hodges (June 26, 2015), abortion rose to take its place as the dominant concern to external audiences through press releases. ${ }^{6}$ It is notable that this is also a time period when the pro-life movement achieved considerable success in state legislatures rolling back funding and access to abortion facilities (e.g., Nash et al. 2018). In other words, the focus on abortion could also signal power and majority status.

\section{Homosexuality}

Another issue associated with the Christian Right is the belief that homosexuality is a sin and that public policy should not incentivize homosexuality by providing equal (often called "special") rights. From Anita Bryant through the AIDS Crisis and to the legal recognition of same-sex marriage, social conservatives have maintained that homosexuality is against the Bible and against nature. As advocates of complementarianism (men and women have different, complementary roles), FRC is clear that it believes homosexuality is unnatural, will lead to a significant change in American culture, and perhaps threaten the health and well-being of heterosexual Christians. In Figure 1, we track the usage of the words homosexual,

\footnotetext{
${ }^{6}$ Another version of this figure shown with one issue highlighted at a time appears in Appendix Figure A6.
} 


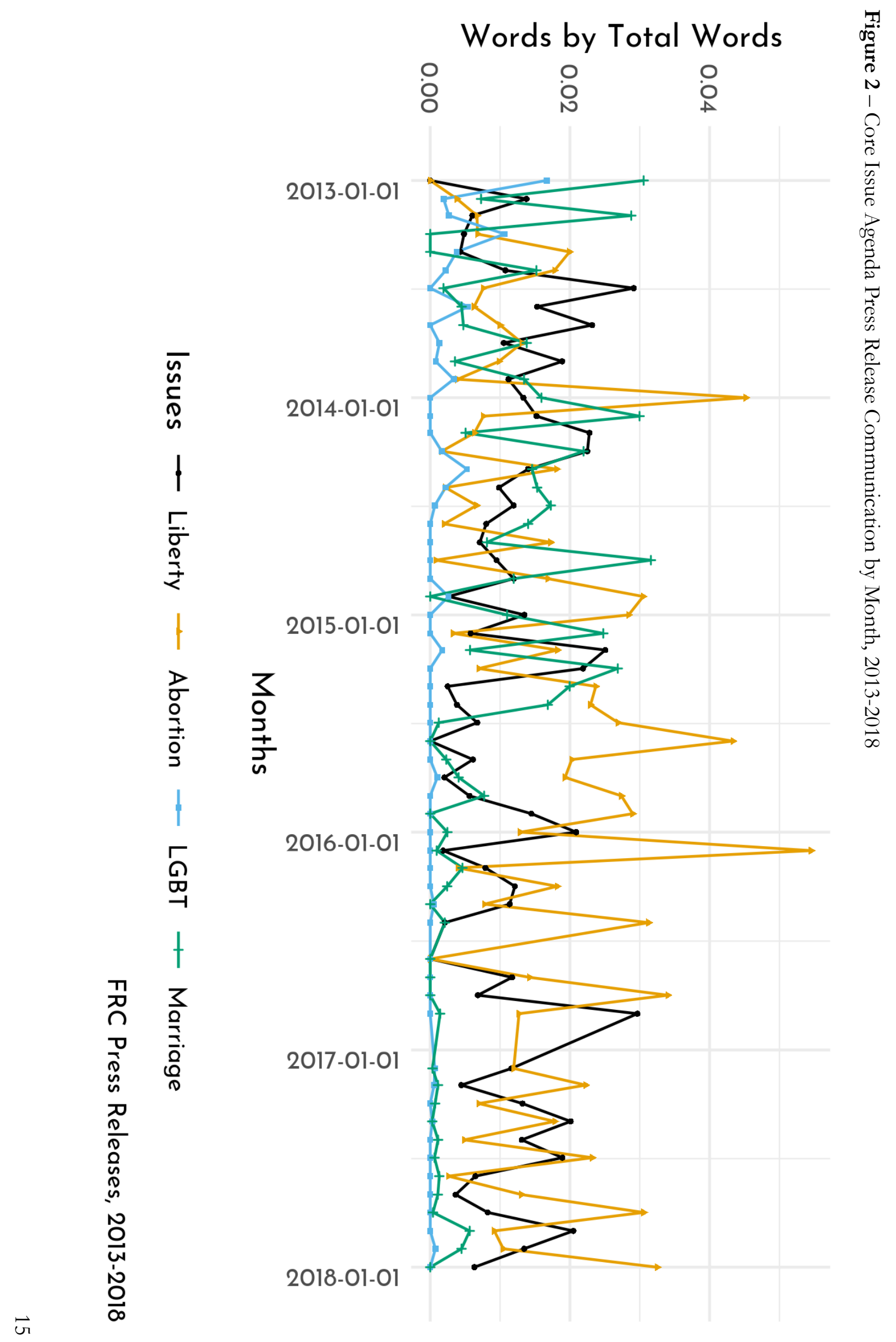


homosexuality, gay, lesbian, bisexual, transgender, and transsexual. Again, the apparent centrality of this issue might lead to an assumption that it would make a regular appearance in internal emails.

We find that between 2008-2011 LBGT rhetoric factors into the internal messaging less than abortion rhetoric. The spikes in 2008 map onto the wider political discussions around California's Proposition 8 which sought to establish a state constitutional amendment defining marriage as between a man and woman only. Once the ballot initiative passed, the mentions are dialed back. Like abortion, the spike in 2009 seems to map onto the debate over Obamacare. It is noticeable that at the beginning of 2010 the rhetoric begins to increase. There were two key events during this time. First, in February, FRC was active in lobbying against the House of Representatives' condemnation of the Ugandan Anti-Homosexuality Bill (HRes. 1064). Second, on April $14^{\text {th }}$, Obama signed an executive order changing DHHS rules to allow hospital visitation and decision-making rights for gay and lesbian partners. Of course, 2010 was also the mid-term elections, so these combined factors seem to indicate that during that year FRC believed it was politically strategic to educate, interpret, and motivate constituents on this issue. Setting aside 2011 (due to low n), the LGBT rhetoric appears significantly less from 2012 onwards. Two related external factors worth noting might have had an impact on this shift in rhetoric. First, the dominant reason why the FRC mentions homosexuality is in context of samesex marriage (see Figure A8) - the two trends track closely. Therefore, once Obergefell was decided, mentions of LGBT specifically dwindle to nearly non-existent. ${ }^{7}$

Second, research demonstrated that from 2000 onwards there was a significant change in attitudes overall in the US towards lesbians and gay men. For example, fewer Americans had negative attitudes towards gay men and lesbians raising children (Drake 2013a); there was more support for gay marriage (Pew 2013); there was more social acceptance of gay men and lesbians

\footnotetext{
${ }^{7}$ It is worth noting here that the rise in discussion of transgender citizens maps differently from 2017 and this needs to be more closely tracked in the future.
} 
(Drake 2013b); and by 2011 around 60\% of Millennials favored gay marriage (Pew 2011).

Specifically, evidence suggests that evangelical young people appear to disagree with antihomosexuality rhetoric (Cooper et. al. 2016; Farrell 2011; Putnam and Campbell 2010) and are more likely to believe homosexuality should be accepted by society (Diamant and Alper 2017). The dialing back of identity-specific rhetoric may indicate market awareness and a recognition that identity specific language resonated less with constituents, particularly younger constituents. ${ }^{8}$

There is some evidence to suggest that these larger social changes have had an impact on Christian Right organizations. In 2011, reparative therapy programs also came to the attention of the wider public through controversial stories about a clinic owned by then presidential candidate Michelle Bachmann's husband, Marcus. In 2012, a key organization of the Christian Right, Exodus International encountered various difficulties and eventually closed in 2013. These events suggest that changing social attitudes did affect some Christian Right organizations. Therefore, it is possible that FRC emails reflect a broader strategic shift away from some forms of identity-specific rhetoric.

\section{Marriage}

Figure 1 also tracks the usage of the terms 'marriage' and 'same-sex marriage'. Between 2008 and 2018, marriage appears far more often than LGBT identity-specific terms and is more akin to the usage of the word abortion in its frequent appearance in emails. As noted above, the 2008 spikes map onto three significant events: in May the California Supreme Court struck down the ban on same-sex marriages with weddings beginning in June; in July the US Court of Appeals upheld the 'Don't Ask, Don't Tell' policy banning gay men and lesbians from serving openly in the US military; and in November, the presidential election was held during which Republican candidate McCain endorsed a state's right to define marriage as between a man and a woman.

\footnotetext{
${ }^{8}$ This is a concern for two reasons. First, some argue that there is a graying of CR leadership and worry that they are not reaching out sufficiently to young adults. Second, there is a decline in religiosity, particularly among young adults, and this demographic shift could have a significant impact on potential supporters of Christian Right organizations (see, e.g., Margolis 2018).
} 
The early spike in 2009 reflects a number of state-level policy and legal changes allowing for same-sex marriage - e.g., in Arizona, Hawaii, Colorado, Vermont, New Hampshire, Iowa, Maine, and New York all taking place between February and April. Whereas political discourse in 2008 and early 2009 was centered around 'marriage', after the 2008 election the rhetoric appears to be dialed back until the mid-term elections.

From 2012 through 2014, marriage rhetoric becomes a much more prominent feature of FRC's internal communication. Marriage and same sex marriage are deployed more than abortion or identity-based LGBT language. In February 2012, the US Court of Appeals for the Ninth Circuit rules California's Proposition 8 unconstitutional. On May 9 ${ }^{\text {th }}$, President Obama announced that he believed same-sex couples should be allowed to marry and endorsed civil rights for gay men and lesbians. This corresponds with a significant rise in mentions of marriage in FRC emails. Later in the year, marriage stays on their political radar, though at a lower volume, with Maine, Washington, and Maryland becoming the first states to legalize same-sex marriage by popular vote.

In early 2013, the decision by the Pentagon to extend some marriage benefits to samesex couples maps onto a similarly noticeable rise in FRC marriage rhetoric. In May, Rhode Island, Delaware, and Minnesota all legalize same-sex marriage. Then early in the summer the US Supreme Court finds parts of DOMA unconstitutional followed by dismissing an appeal regarding Proposition 8. All of this serves to keep marriage central to political discourse.

Marriage rhetoric spikes again in January 2014 as the US Supreme Court halts gay marriages in Utah during a state appeals process, only to be followed by the US Supreme Court declining to hear five same-sex marriage appeals in November, which served to allow same-sex marriages to go ahead in five states. The largest spike in marriage rhetoric surrounds the US Supreme Court Obergefell v. Hodges decision in June 2015. Beyond that time, marriage rhetoric plays less of a role in FRC email rhetoric. We are not suggesting that FRC has accepted same-sex 
marriage, however the political environment had shifted and they retreated to focus on the fight for exclusions from rights compliance (as in Masterpiece).

Much of the same analysis can be applied to the press release distribution of marriage rhetoric (see Figure 2). Marriage is quite prominent before mid-2015 (Obergefell) and then drops off almost completely thereafter, with only a few aftershocks. It is also much clearer in the press releases that marriage and abortion do not often occupy the FRC's external communication agenda at the same time. That is confirmed in Figure A9, which shows a sharply negative relationship between their concentration in month-aggregated press releases - when one is present, the other is not.

\section{Liberty}

Our analysis of the liberty theme includes references to 'liberty' and 'freedom'. In 2008 some FRC emails had a banner line of "Life, Family, \& Liberty." Therefore, as a core organizational value, it is unsurprising that 'liberty' appears regularly, as Figure 1 indicates. However, the theme does not register significantly in emails from 2008 through 2010, though from 2012 until late 2014 'liberty' makes a modest but steady climb with a small spike in the autumn of 2014.

Two events occurred in 2012 that altered the political landscape. In Colorado, Masterpiece Cakeshop refused on religious grounds to bake a wedding cake for a gay couple. In Oklahoma, in response to requirement of Obamacare that employees are offered a range of contraceptive options, the owners of Hobby Lobby refused on religious grounds to offer the morning after pill as an option in their employee healthcare plan. FRC was actively supportive of both cases starting with emails about the bakery in July 2012 and the Hobby Lobby lawsuit later in November. FRC also wrote amicus briefs for both cases. Over the next few years, both cases moved in and out of public discourse with the Hobby Lobby case decided by the US Supreme Court in 2014 and the bakery case in 2018. Both cases upheld the conservative Christian cause on grounds of religious liberty, though Masterpiece was narrowly decided. 
In October 2014, Houston mayor Annise Parker issued a subpoena for sermons believed to violate the city's equal rights ordinance. While that case was dropped in early 2015 , the spike in November 2014 coincides with an FRC book launch, The Liberty Threat, written by James Tonkowich that cited the Houston case. Of course, both issues were highlighted around the time of the midterm elections.

In early 2015 the rhetoric changes significantly. Throughout 2015 and 2016, liberty spikes far more than any other theme we consider. In Figure 1, liberty is comparatively the most repeated theme, outscoring abortion, homosexuality, and, other than around the Obergefell decision, marriage. The employ of liberty at the start of 2015 signals a new fight they had begun with Masterpiece and would continue after Obergefell: fighting to limit the application of rights observance to conservative Christians. Many of the emails connect issues of liberty with homosexuality: "the rampant LGBT agenda is a direct assault on our right to freedom of religion” (March 16, 2015). Policies supporting transgender citizens are of particular concern around this time, too.

But "liberty" also continued to be tied to traditional topics of school choice, prayer in school, and a fire fighter who was allegedly fired from his job due to a self-published Bible study booklet. April 2015 sees an increase in the number of emails citing religious liberty, all soliciting donations towards a "Free to Believe" matching grant. Specifically, FRC had a goal of raising $\$ 150 \mathrm{k}$ by the end of April. Once Trump is elected in 2016, liberty remains a key theme but is more in line with the others.

It is clear that liberty rises and falls as the status of the Christian Right shifts. The most dramatic inflection point is the Obergefell decision where the movement moves from majoritarian to the minority position seeking rights protections. From some perspectives, this follows the long slide toward minority status embodied in abortion politics (Lewis 2017). But it is not static and the FRC is less compelled to use protectionist "liberty" language after Trump is elected. 
Liberty does appear in the press releases (Figure 2), but its status relative to abortion is inverted compared to the email pattern - compared to abortion, liberty is much less frequently invoked in press releases. In fact, liberty goes on hiatus in the press releases immediately after the Obergefell decision. Liberty returns to steady usage from late 2015 onward, but its prevalence decouples from marriage, which is now infrequently used. This indicates that religious liberty is not simply a reframing of marriage concerns, but a new agenda item. While liberty and freedom are powerful symbolic terms that have a deep resonance with Americans (e.g., Jelen 2005), they are not indicators of majoritarianism and power.

Across the post-Obergefell period, the email concentration on liberty seems to enable FRC to position themselves to their followers as a threatened minority in need of protection, which resonated with the rising populist, anti-federal government narrative of the 2016 elections. To confirm that the language did indeed shift, Figure 3 shows the results of regression models interacting the communication channel and whether the monthly concentration of rhetoric on each theme came before or after the Obergefell decision in June 2015. In the pre-Obergefell era, the press releases featured a higher concentration of liberty rhetoric, while it was significantly less common in the post-Obergefell period (if two lines do not overlap, it is statistically significant at the $90 \%$ level). The abortion gap was already present in the pre period, but grows substantially in the post period; an abortion focus is even less likely in the emails and more likely in the press releases.

Figure 3 - How Liberty and Abortion Rhetoric Presence Shifted from Pre to Post Obergefell 

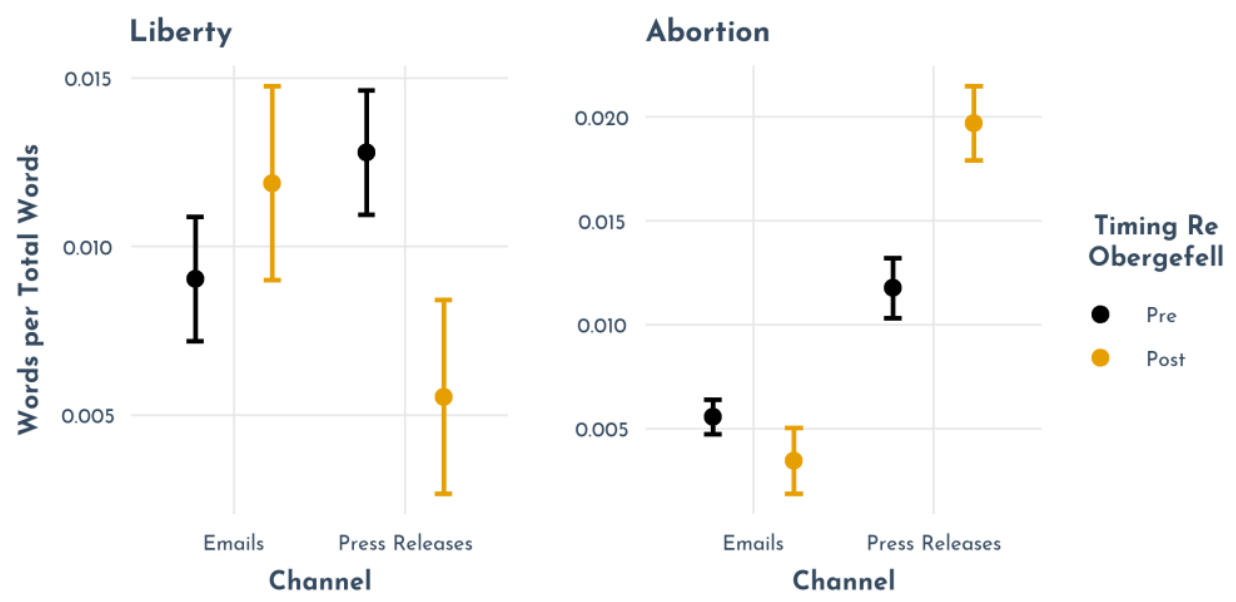

\section{The Link Between Internal and External Communication}

As discussed earlier, messaging must be flexible to serve many masters, but existing work suggests, in parallel with our first hypothesis, that interest groups will coordinate their communication channels. Interest groups are forced to adopt frames that will appeal to legislators but not offend members (e.g., Beyers 2004; Trapp and Laursen 2017). Organized interests employ "all directional advocacy" (Browne 1998), focusing their communicative efforts wherever they will bear fruit. When groups are not able to successfully establish and negotiate insider connections, they take their case to members and to the public (e.g., Dür and Mateo 2013; Kollman 1998; Schattschneider 1960).

But, there are good reasons why communication to different audiences may not correlate. One possibility is simply that different divisions within large organizations handle different communication channels and an organization's message drifts. ${ }^{9}$ In this particular case, FRC indicated that they have separate teams writing emails and press releases, but they coordinate efforts. Our approach focuses on the needs of different audiences - managing access to legislators may not mesh with the needs of managing the membership. Access is granted on the basis of power and agreement, whereas the membership may be motivated by minority status

\footnotetext{
${ }^{9}$ One reviewer suggested this and another reason - emails are often fundraising and that would distort their issue communication. Nearly every email asks for donations, however, indicating that such talk may dilute, but does not distort their issue communication. There are about 3,500 mentions of "donate" and "contribute" in the emails, which is about 1,000 more than there are emails.
} 
and disagreement with society and current policy directions. The importance attached to issues may differ and the language profile of successful arguments may differ. That is, members may more successfully mobilize on the pain of loss, coupled with doing the Lord's work in the case of religious organizations, rather than gain. On the other hand, legislators are more likely to respond to powerful, successful groups making majoritarian arguments. This is our second hypothesis - that agendas in different channels will not correlate and the pattern in each will follow the needs of advocating with that audience.

One way to gain leverage on the needs of the audience is to examine the focus on issues as the political environment changes. The logics of managing internal and external communications may be motivated by organizational elites recognizing a shift from a majority to minority status on an issue. For example, above we noted the great shift in FRC rhetoric around the Obergefell decision. The judicial and social acceptance of same-sex marriage clearly repositioned FRC in the minority. Given the extent of the threat posed and loss of majority status, one might expect FRC's communication around this issue to align in frequency between the emails and press releases. Alternatively, abortion politics has not changed greatly since the 1970s. Opinion distributions have been stable (e.g., Saad 2017) and while legislatures continue to churn out restrictive policies, federal courts have consistently rejected the most restrictive ones. As the press release data suggest, abortion is credible material for the FRC to address, it signals their efficacy, and it may be flexible enough to allow the internal and external communication streams to be independent.

Figure 4 tests just that. It displays the link in monthly concentrations of communication between emails and press releases for the 4 core issues captured in two flavors - the raw counts of terms and the relative counts (per the total word count that month). Abortion communication from emails and press releases is not significantly correlated $(r=.16, \mathrm{p}=.23)$; neither is the relative content significantly correlated. Strikingly, the communication in emails and press releases about liberty and freedom is not significantly correlated either $(r=.17, p=.20)$, while the relative counts 
are almost completely independent $(r=.01, p=.95)$. We have already seen that the liberty language came to dominate email communication after Obergefell, but it did not feature nearly as prominently in press releases and was quite variable in concentration. These distinct patterns are reflected dramatically in Figure 4. 


The use of LGBT language is significantly linked between the two communication channels, but the counts are so low in the press releases that the link is not particularly meaningful. Surely this pattern is part of the much more extensive campaign of discussing marriage. Seen in the upper right corner of Figure 4, the marriage counts (and relative counts) are strongly correlated between monthly emails and press releases $(r=.58, p<.01$ for the raw counts).

Even in the cases of issues that host correlations between the communication channels, it is important to point out how divergent some months are. Focusing on the case of marriage, there is a month with nearly 60 mentions of the word marriage in press releases and zero mentions in their emails; on the flip side, there is a month with just shy of 200 mentions of marriage in email communication and zero mentions in the press releases. These months are not common, obviously, but they do exist and serve to highlight just how flexible the FRC is in its communication programming across channels.

To the extent that previous work has contemplated this question, it suggests that frames are strategically chosen for wide appeal and that their influence hinges on connecting supporters with policymakers to move or halt existing legislation. The disjuncture with the literature could not be greater since our evidence aggregates frames up to the agenda-level. Therefore, in many cases, the state of the political world as read by FRC supporters is considerably different than what the FRC is suggesting to its press release constituency, not just in framing, but in terms of what issues are important at a particular time. These indications of flexibility of messaging across channels undoubtedly reflect sophisticated, strategic communications, but the dissonance also raises questions about representation. Below, we explore this further by assessing what bills lobbied on by FRC are noted as important in emails to FRC supporters.

\section{Communicative Links to Lobbying}

It would be ideal to validate the lack of connection between communication channels with other data. Fortunately, we have another source to examine - the degree to which email 
subscribers are informed about FRC lobbying. The literature is not united on this point, but the primary assumption is that insider influence depends on a tight feedback loop where groups mobilize members (in the case of membership groups) to communicate their position back to legislators (e.g., Ainsworth and Sened 1993; Lowery and Marchetti 2012). But, since groups tend to lobby allies (Baumgartner and Leech 1999; Hall and Wayman 1990; Hojnacki and Kimball 1998) and friendly committees (Holyoke 2003), member mobilization is not immediately necessary in most cases - allied policymakers know the organization and do not need a thousand postcards to sponsor legislation. This is especially true when groups have a presence in a member of Congress's (MOC) district or state (Hojnacki and Kimball 1998, 2001; Langbein and Lotwiss 1990). Perhaps only in cases where organized interests need to coordinate MOCs and group members will they talk explicitly about their lobbying efforts to member/supporters. Put differently, we think it unlikely that organizations inform their membership about every legislative effort, but one might assume requirements of representation would lead to identifiable issue resonance across channels.

We searched emails for bills on which the FRC reported lobbying. The bills with the most mentions are presented in Figure A10 and the Employment Non-Discrimination Act (ENDA) tops the chart with 83 mentions, perhaps because it has been "introduced in every Congress since 1994 except the 109 $9^{\text {th }}$ (Wikipedia 2018). Clearly the FRC considers establishing the right to non-discrimination based on sexual orientation as a deep and persistent threat. Most of the remainder of the top bills mentioned deal with abortion and contraception.

Figure 5 highlights the variation in bill mentions over time. On average, it is not likely that an email to members includes a reference to a bill. The average (.144 overall) hovers around .114 per email through 2013 and then jumps up thereafter to .202 per email; on average 3.1 bills were mentioned each month. There were 234 total bill mentions in the emails, though it is 
important to note that only 48 bills (of the 288 searched) were mentioned by name at least once in the emails (about $17 \%$ of bills). ${ }^{10}$

Of course, this could be a limitation of our inflexible search method that requires the bill's name be mentioned. "ENDA", for instance, would not be counted by this method. FRC could also talk generally about their efforts to stop employment provisions that would impede Christian religious freedom (to discriminate), but that would not be picked up either. So, this is an admittedly conservative estimate of how much they communicate their lobbying activity. But it is also a useful one since contacting MOCs about an issue would be facilitated by mention of bill titles.

Figure 5 - Relative Mentions of FRC-Lobbied Bills in Emails to Members

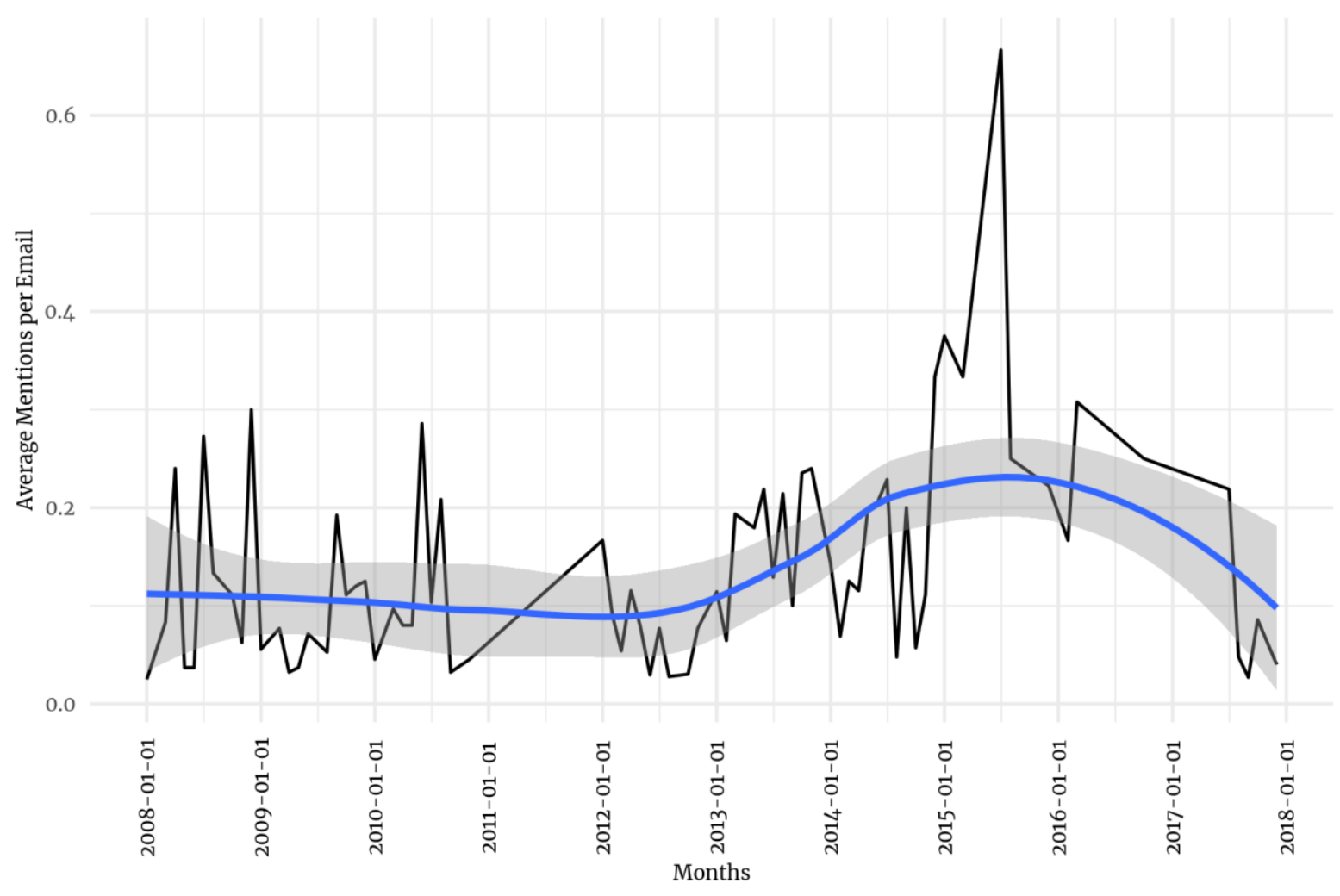

Putting those objections aside for the moment, the FRC communicates very little about its lobbying activity by this measure. The mentions are sporadic, they are concentrated around a

\footnotetext{
${ }^{10}$ Bill mentions are not a simple function of having more emails to mention them, which we confirm in Figure A11 - there is only a weak, but statistically significant relationship between bill mentions and the monthly email count.
} 
few time periods, and they are focused on a few handfuls of bills. For example, the significant spike in early 2015 reflects the mentions of only four bills: two around abortion and two around religious freedom. The spike in July 2015, just after the Obergefell decision, reflects the mentions of only three bills: one around abortion and two around religious freedom. Once Trump is elected, there is very little mention of legislation lobbied in emails. It is hard to say just how this meshes with expectations since there is no research that provides estimates of the proportions of groups' agendas that are communicated to the public. But, the low level of coordination between the two channels of communication does appear to reinforce the notion that FRC is actively lobbying on a range of legislation that is not mentioned to FRC supporters. This evidence suggests, at the least, a failure of the feedback loop between group leaders and supporters and, potentially, could be taken as an indication of a lack of representational mandate. It does not appear that FRC is lobbying outside of its self-defined mandate, but it is impossible to evaluate the team if there's no public record of wins and losses.

\section{Conclusion}

The evidence here focuses on the way in which flexibility of messaging, which enables FRC to respond to political events and to target particular audiences through various channels, may raise questions about representation. In doing so, we first consider whether communication channels are coordinated or constrained by the messaging in the other. We acknowledge that organized interests must maintain multiple communication channels simultaneously, and argue that each has its own demand structure. For example, messaging with supporters must demonstrate the possibility and pain of loss, while press releases may focus on articulating the power of the group to incentivize government officials' support. The agendas presented internally and externally can vary significantly to the extent that issues overlap with these status concerns. Nowhere is this seen more clearly than in the agendas represented in the two main communication channels post Obergefell. Email subscribers hear rarely about abortion and often about liberty in this time period, while press release audiences hear extensively about abortion 
and far less about liberty. We suggest this evidence supports hypothesis 2 - communicated agendas will conform to the separate needs of channel audiences.

Secondly, our findings demonstrate independence of interest group communication across channels: flexible in their rhetoric as they adapt to shifting political events, they tailor messages between in-group and external audiences, and often present different agendas to these audiences. Moreover, supporters are told quite selectively about FRC lobbying efforts. FRC exercises a great deal of control over their communications such that separate channels appear to operate independently. Our evidence calls into question the types and extent of constraints previously identified in the analysis of only external messages, especially the need for consistency across constituencies. Given the data resources available to researchers now to handle text, we are just beginning to investigate the critically important feedback loop within organized interests.

Our findings echo others in questioning assumptions that religious interest groups are somehow more constrained in their messaging. We know that, at least since the rise of the Christian Right, such groups have grown in political sophistication (e.g., Moen 1994; Wilcox and Robinson 2010). What our findings add to this understanding is that religious interest groups are able to demonstrate a high level of strategic communication with independent, targeted messaging for particular audiences that closely tracks with developing events. This level of flexibility in messaging likely demonstrates strategically sophisticated and politically nuanced interest group engagement.

Importantly, our findings raise some troubling questions about a key democratic problem of organized interests - the disconnect between supporters (principals) and leadership (agents). We know that leaders exercise discretion in their communication with members and gain latitude in their political affairs from successful group maintenance, but we doubt many envisioned the empirical patterns presented in this paper. By examining internal alongside external messages, we can begin to see how flexibility can eventually raise questions about good faith representation. At its worst, organized interests may be playing a shell game with issue representation between 
members and elected officials. At its best, there are difficult time lags to resolve connecting members to elected officials, though this interpretation does little to help make sense of the orthogonal press release agenda patterns. Pursuing such a research agenda should help us understand disconnects between citizens and government and the associated questions surrounding political trust, engagement, and coalition formation. 


\section{References}

Achen, Christopher H., and Larry M. Bartels. 2017. Democracy for Realists: Why Elections Do Not Produce Responsive Government. Princeton: Princeton University Press.

Ainsworth, Scott, and Itai Sened. 1993. "The Role of Lobbyists: Entrepreneurs with Two Audiences." American Journal of Political Science 37(3): 834-866.

Andsager, Julie. 2000. "How interest groups attempt to shape public opinion with competing new frames." Journalism and Mass Communication Quarterly 77 (3): 577-592.

Andrews, Kenneth T., and Bob Edwards. 2004. "Advocacy Organizations in the U.S. Political Process." Annual Review of Sociology 30:479-506.

Bauer, Raymond A., Ithiel de Sola Pool, and Lewis A. Dexter. 1963. American Business and Public Policy. New York: Atherton.

Baumgartner, Frank R., Jeffrey M. Berry, Marie Hojnacki, David C. Kimball, and Beth L. Leech. 2009. Lobbying and Policy Change: Who Wins, Who Loses, and Why. Chicago: University of Chicago Press.

Baumgartner, Frank R. and Bryan D. Jones. 1993. Agendas and Instability in American Politics. Chicago: University of Chicago Press.

Baumgartner, Frank R., and Beth L. Leech. 1998. Basic Interests: The Importance of Groups in Politics and in Political Science. Princeton: Princeton University Press.

Baumgartner, Frank R., Suzanna Linn, and Amber E. Boydstun. 2009. "The Decline of the Death Penalty." In Winning with Words: The Origins and Impact of Political Framing. New York: Routledge. pp. 159-184.

Bentley, Arthur F. 1995 [1908]. The Process of Government: A Study of Social Pressures. New Brunswick: Transaction.

Beyers, Jan. 2004. "Voice and Access: Political Practices of European Interest Associations." European Union Politics 5(2): 211-240.

Brader, Ted. 2006. Campaigning for Hearts and Minds: How Emotional Appeals in Political Ads Work. Chicago: University of Chicago Press.

Brader, Ted, and George Marcus. 2013. "Emotion and Political Psychology." In The Oxford Handbook of Political Psychology, $2^{\text {nd }}$ ed. Leonie Huddy, David O. Sears, and Jack S. Levy, eds. New York: Oxford University Press. pp. 165-204.

Browne, William P. 1998. "Lobbying the public: all directional advocacy." In Interest Group Politics, Allan J. Cigler and Burdett Loomis, eds. Washington, DC: CQ Press. pp. 343-363.

Burack, Cynthia. 2008. Sin, Sex, and Democracy: Antigay Rhetoric and the Christian Right. Albany: SUNY Press.

Calfano, Brian R. 2010. "Prophetic At Any Price? Clergy Political Behavior and Utility Maximization.” Social Science Quarterly 90(1): 88-102.

Calfano, Brian R., and Paul A. Djupe. 2009. "God talk: Religious cues and electoral support.” Political Research Quarterly 62 (2): 329-339.

Campbell, David E., and Monson, J. Quin. 2008. "The religion card: Gay marriage and the 2004 presidential election." Public Opinion Quarterly 72 (3): 399-419.

Carnes, Nicholas, and John B. Holbein. N.D. "Do Public Officials Exhibit Social Class Biases when they Handle Casework? Evidence from Multiple Correspondence Experiments." Unpublished manuscript. http://people.duke.edu/ nwc8/carnes and holbein.pdf

Chalmers, Adam W., and Paul A. Shotton. 2016. "Changing the Face of Advocacy? Explaining Interest Organizations' Use of Social Media Strategies." Political Communication 33: 374-391.

Chong, Dennis, and James N. Druckman. 2008. "Framing Public Opinion in Competitive Democracies." American Political Science Review 101: 637-655.

Cooper, Betsy, Daniel Cox, Rachel Lienesch, and Robert P. Jones. 2016. "Beyond Same-Sex Marriage: Attitudes on LGBT Nondiscrimination Laws and Religious Exemptions from the 2015 American Values Atlas.” Public Religion Research Institute, February 18. Available at 
http://www.prri.org/research/poll-same-sex-gay-marriage-lgbt-nondiscrimination-religiousliberty

Davis, Darren W., and Brian D. Silver. 2004. "Civil Liberties vs. Security: Public Opinion in the Context of the Terrorist Attacks on America." American Journal of Political Science 48(1):28-46.

Diamant, Jeff, and Becka A. Alper. 2017. "Though still conservative, young evangelicals are more liberal than their elders on some issues." http://www.pewresearch.org/facttank/2017/05/04/though-still-conservative-young-evangelicals-are-more-liberal-than-theirelders-on-some-issues /

Djupe, Paul A. and Christopher P. Gilbert. 2008. "Politics and Church: Byproduct or Central Mission?” Journal for the Scientific Study of Religion 47(1): 45-62.

Drake, Bruce. 2013a. "Fewer Americans have negative views of more gays raising children." http://www.pewresearch.org/fact-tank/2013/06/25/fewer-americans-have-negative-viewsof-more-gays-raising-children/

Drake, Bruce. 2013b. "As more Americans have contacts with gays and lesbians, social acceptance rises." http://www.pewresearch.org/fact-tank/2013/06/18/as-more-americanshave-contacts-with-gays-and-lesbians-social-acceptance-rises/

Dür, Andreas, and Gemma Mateo. 2013. "Gaining access or going public? Interest group strategies in five European countries.” European Journal of Political Research 52: 660-686.

Farrell, Justin. 2011. "The Young and the Restless? The Liberalization of Young Evangelicals." Journal for the Scientific Study of Religion 50(3): 517-532.

Godwin, R. Kenneth. 1988. One Billion Dollars of Influence: The Direct Marketing of Politics. Chatham, NJ: Chatham House.

Gray, Virginia, and David Lowery. 1996. "A Niche Theory of Interest Representation.” Journal of Politics 58(1): 91-111.

Gray, Virginia, and David Lowery. 1998. "To lobby alone or in a flock: Foraging behavior among organized interests." American Politics Quarterly 26: 5-34.

Green, John C., Mark J. Rozell, and Clyde Wilcox, eds. 2006. The Values Campaign? The Christian Right and the 2004 Elections. Georgetown University Press.

Hadden, Jeffrey K. 1969. The gathering storm in the churches. New York: Doubleday.

Hall, Richard L., and Frank M. Wayman. 1990. "Buying Time: Moneyed Interests and the Mobilization of Bias in Congressional Committees." American Political Science Review 84(3): $797-$ 820.

Heinz, John P., Edward O. Laumann, Robert L. Nelson, and Robert H. Salisbury. 1993. The Hollow Core: Private interests in national policy making. Cambridge: Harvard University Press.

Hildreth, Anne. 1994. "The Importance of Purposes in "Purposive" Groups: Incentives and Participation in the Sanctuary Movement." American Journal of Political Science 38(2): 447-463.

Hofrenning, Daniel J. 1995. In Washington but not of it: The prophetic politics of religious lobbyists. Temple University Press.

Hojnacki, Marie. 1997. "Interest groups' decisions to join alliances or work alone.” American Journal of Political Science 41: 61-87.

Hojnacki, Marie, and David C. Kimball. 1998. "Organized Interests and the Decision of Whom to Lobby in Congress." American Political Science Review 92(4): 775-90.

Holyoke, Thomas T. 2003. "Choosing battlegrounds: Interest group lobbying across multiple venues." Political Research Quarterly 56(3): 325-336.

Huddy, Leonie, Stanley Feldman, Charles Taber, and Gallya Lahav. 2005. "Threat Anxiety and Support of Antiterrorism Policies.” American Journal of Political Science 49: 593-608.

Jelen, Ted G. 2005. "Political Esperanto: Rhetorical Resources and Limitations of the Christian Right in the United States." Sociology of Religion 66: 303-321.

Jerit, Jennifer. 2008. "Issue Framing and Engagement: Rhetorical Strategy in Public Policy Debates." Political Behavior 30: 1-24. 
Jones, Bryan D., Frank R. Baumgartner, and Jeffery C. Talbert. 1993. "The destruction of issue monopolies in Congress." American Political Science Review 87(3): 657-671.

Kahneman, Daniel, and Amos Tversky. 1979. "Prospect Theory: An Analysis of Decision under Risk." Econometrica 47(2): 263.

Kalla, Joshua, Frances Rosenbluth, and Dawn Teele. 2018. “Are You My Mentor? A Field Experiment on Gender, Ethnicity, and Political Self-Starters." Journal of Politics 80(1): 337-341.

Knutson, Katherine E. 2011. "Breaking the Chains?: Constraint and the Political Rhetoric of Religious Interest Groups." Politics and Religion 4 (2): 312-337.

Knutson, Katherine E. 2013. Interfaith Advocacy: The Role of Religious Coalitions in the Political Process. New York: Routledge.

Koch, Jeffrey W. 1993. “Assessment of Group Influence, Subjective Political Competence, and Interest Group Membership." Political Behavior 15(4): 309-325.

Kollman, Kenneth. 1998. Outside lobbying: Public opinion and interest group strategies. Princeton: Princeton University Press.

Langbein, Laura I., and Mark A. Lotwis. 1990. "The Political Efficacy of Lobbying and Money: Gun Control in the U.S. House, 1986.” Legislative Studies Quarterly 15(3): 413-440.

Leifeld, Philip, and Volker Schneider. 2012. "Information exchange in policy networks." American Journal of Political Science 56(3): 731-744.

Lewis, Andrew R. 2017. The Rights Turn in Conservative Christian Politics: How Abortion Transformed the Culture Wars. New York: Cambridge University Press.

Lewis, Andrew R. 2014. "Staffing the Front Lines of the Culture War: Constituency Religious Effects on Assignment to the Senate Judiciary Committee." Congress \& the Presidency 41(2): 167-189.

Loomis, Burdett A., and Allan J. Cigler. 2007. Interest Group Politics, $7^{\text {th }}$ ed. Washington, DC: CQ Press.

Lowery, David, and Holly Brasher. 2004. Organized Interests and American Government. Long Grove, IL: Waveland Press.

Lowery, David and Kathleen Marchetti. 2012. "You don't know Jack: Principals, Agents, and Lobbying." Interest Groups \& Advocacy 1(2): 139-170.

Margolis, Michele F. 2018. From Politics to the Pews: How Partisanship and the Political Environment Shape Religious Identity. Chicago: University of Chicago Press.

McCrain, Joshua. Forthcoming. "Revolving Door Lobbyists and the Value of Congressional Staff Connections." Journal of Politics.

McFarland, Andrew S. 1984. Common Cause: Lobbying in the Public Interest. Chatham: Chatham House.

Miller, Joanne M., and Jon A. Krosnick. 2004. "Threat as a Motivator of Political Activism: A Field Experiment." Political Psychology 25(4): 507-23.

Moe, Terry. 1980. The Organization of Interests. Chicago, IL: University of Chicago Press.

Moen, Matthew C. 1994. "From revolution to evolution: The changing nature of the Christian right." Sociology of Religion 55(3): 345-357.

Nash, Elizabeth, Rachel B. Gold, Lizamarie Mohammed, Zohra Ansari-Thomas, and Olivia Cappello. 2018. "Policy Trends in the States, 2017." https://www.guttmacher.org/article/2018/01/policy-trends-states-2017 Accessed 2-12-19.

Neiheisel, Jacob R. and Paul A. Djupe. 2008. "Intra-Organizational Constraints on Churches' Public Witness." Journal for the Scientific Study of Religion 47 (3): 427-441.

Nownes, Anthony J. 1999. "Solicited Advice and Lobbyist Power: Evidence from Three American States." Legislative Studies Quarterly 24(1): 113-123.

Nownes, Anthony J., and Patricia Freeman. 1998. "Interest group activity in the states." The Journal of Politics 60.1: 86-112. 
Olson, Laura O. 2002. "Mainline Protestant Washington Offices and the Political Lives of Clergy." In The Quiet Hand of God, Robert Wuthnow and John H. Evans, eds. Berkeley: University of California Press.

Olson, Mancur. 1965. The Logic of Collective Action: Public Goods and the Theory of Groups. Cambridge, MA: Harvard University Press.

Pew. 2011. "The Generation Gap and the 2012 Election; Section 8: Domestic and Foreign Policy Views." http://www.people-press.org/2011/11/03/section-8-domestic-and-foreignpolicy-views/

Pew. 2013b. "Changing Attitudes on Same Sex Marriage, Gay Friends and Family." http://www.people-press.org/2013/06/06/changing-attitudes-on-same-sex-marriage-gayfriends-and-family/

Putnam, Robert D. 2000. Bowling Alone: The Collapse and Revival of American Community. New York: Simon \& Schuster.

Putnam, Robert D., and David E. Campbell. 2010. American Grace: How Religion Divides and Unites Us. New York: Simon and Schuster.

Ray, John. 2018. "Walk this way, talk this way: legislator speech and lobbying." Interest Groups \& Advocacy 7(2): 150-172.

Rohlinger, Deana A. 2002. "Framing the Abortion debate: Organizational Resources, Media Strategies, and Movement- Countermovement Dynamics." Sociological Quarterly 43(4): 479507.

Rose, Max, and Baumgartner, Frank R. 2013. "Framing the poor: Media coverage and US poverty policy, 1960-2008." Policy Studies Journal 41(1): 22-53.

Rothenberg, Lawrence. 1988. "Organizational Maintenance and the Retention Decision in Groups.” American Political Science Review 82(4): 1129-52.

Rowley, Timothy I. and Moldoveanu, Mihnea, 2003. "When will stakeholder groups act? An interest-and identity-based model of stakeholder group mobilization." Academy of Management Review 28(2): 204-219.

Rozell, Mark J., and Clyde Wilcox. 1996. "Second coming: The strategies of the new Christian right.” Political Science Quarterly 111(2): 271-294.

Saad, Lydia. 2017. "U.S. Abortion Attitudes Stable; No Consensus on Legality." https:// news.gallup.com/poll/211901/abortion-attitudes-stable-no-consensus-legality.aspx

Salisbury, Robert H. 1969. "An Exchange Theory of Interest Groups." Midwest Journal of Political Science 13:1-32.

Schattschneider, Elmer E. 1960. The Semi-Sovereign People. New York: Holt, Rhinehart and Winston.

Schlozman, Kay Lehman and John T. Tierney. 1983. "More of the Same: Washington Pressure Activity in a Decade of Change." Journal of Politics 45(2): 351-77.

Shields, Jon A. 2009. The Democratic Virtues of the Christian Right. Princeton: Princeton University Press.

Silge, Julia, and David Robinson. 2016. "tidytext: Text Mining and Analysis Using Tidy Data Principles in R.” Journal of Open Source Software 1(3): 37. doi: 10.21105/joss.00037.

Skocpol, Theda. 2004. Diminished Democracy: From Membership to Management in American Civic Life. Norman: University of Oklahoma Press.

Smith, Christian. 1998. American Evangelicalism: Embattled and Thriving. University of Chicago Press.

Smith, Christopher. 2014. Dismptive Religion: The Force of Faith in Social Movement Activism. New York: Routledge.

Snow, David A; E. Burke Rochford, Steven K. Worden, and Robert D. Benford. 1986. "Frame Alignment Processes, Micromobilization, and Movement Participation. "American Sociological Review 51(5): 464-481. 
Sullivan, John L., James Piereson, and George E. Marcus. 1982. Political Tolerance and American Democracy. Chicago, IL: The University of Chicago Press.

Tajfel, Henri. 1970. "Experiments in Intergroup Discrimination." Scientific American 232: 96-102.

Terkildsen, Nayda, Frauke I. Schnell, and Cristina Ling. 1998. "Interest groups, the media and policy debate formation: an analysis of message structure, rhetoric and source cues." Political Communication 15: 45-61.

Trapp, N. Leila, and Bo Laursen. 2017. 'Inside out: interest groups' 'outside' media work as a means to manage 'inside' lobbying efforts and relationships with politicians." Interest Groups \& Advocacy 6(2): 143-160.

Victor, Jennifer N. and Gregory Koger. 2016. "Financing friends: How lobbyists create a web of relationships among members of Congress." Interest Groups \& Advocacy 5(3): 224-262.

Wilcox, Clyde. 1994. "Premillennialists at the millennium: Some reflections on the Christian Right in the twenty-first century." Sociology of Religion. 55 (3): 243-261.

Wilcox, Clyde, and Carin Robinson. 2010. Onward Christian Soldiers? The Religious Right in American Politics. 4th ed. Boulder, CO: Westview Press.

Williams, Daniel K. 2012. God's Own Party: The Making of the Christian Right. Oxford University Press.

Wilson, Angelia R., and Cynthia Burack. 2012. "Where liberty reigns and God is supreme': The Christian Right and the Tea Party movement.” New Political Science 34(2): 172-190. 


\section{Supplemental Information Appendix}

Figure A1 - Distribution of Emails Received from the FRC, 2007-2018.

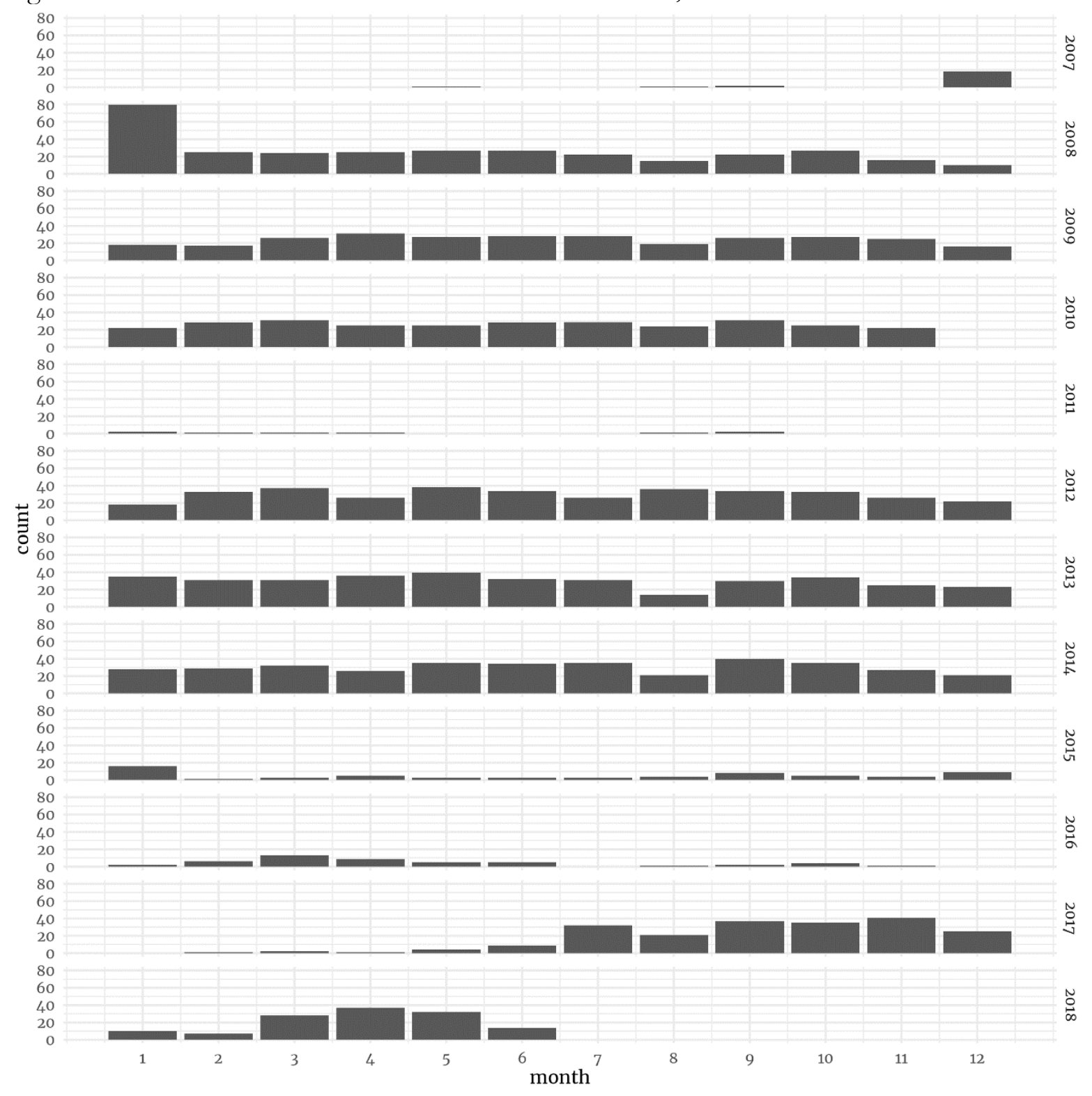


Figure A2 - Press Releases Made by Month by the FRC, 2013-2018

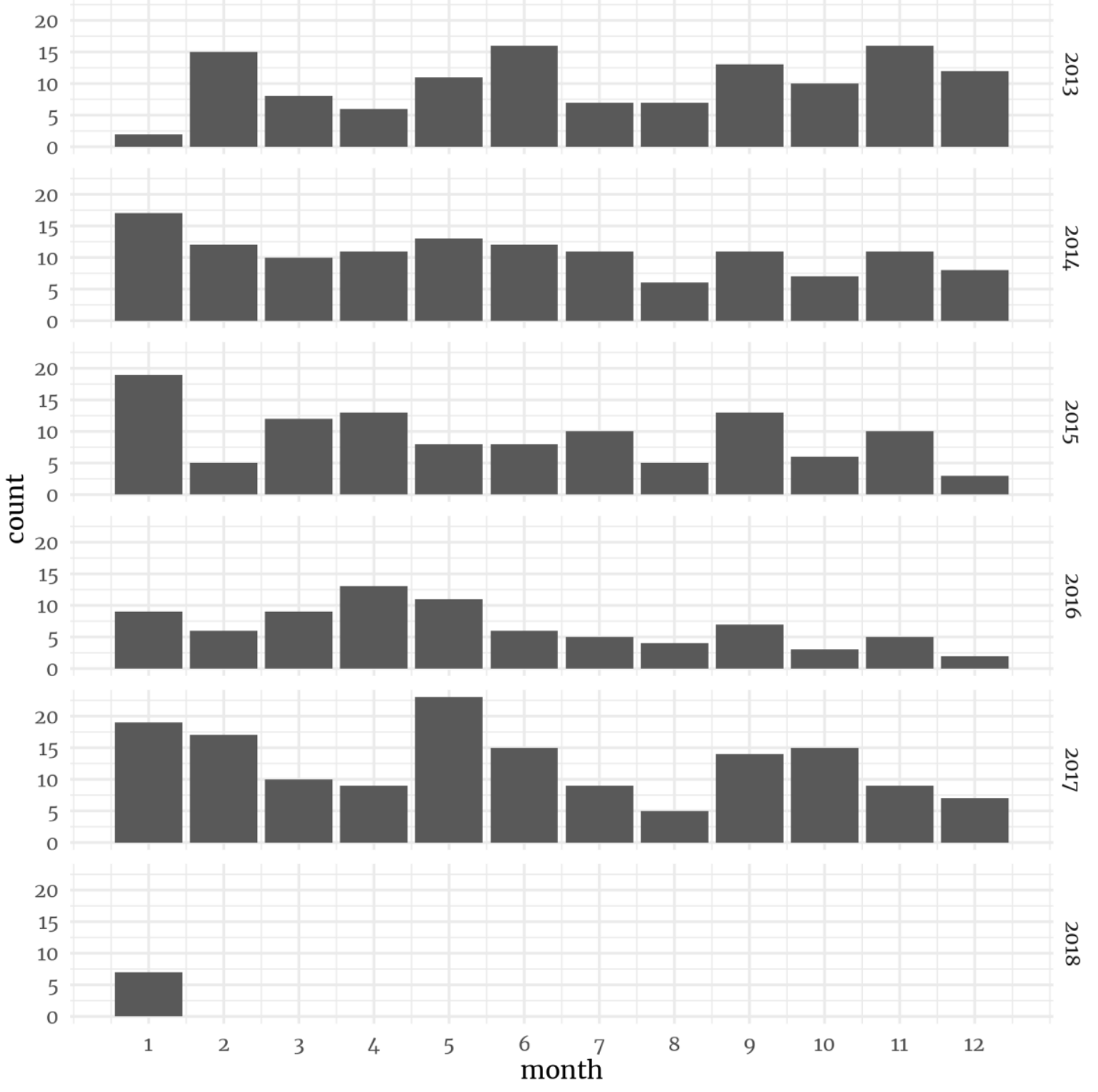


Figure A3 - The Policy Agendas Project Major Issue Areas of FRC Lobbying, 2008-2018




Figure A4 - The Relationship of Simple and Complex Definitions of the Abortion Agenda Simple and Complex Word Counts are Tightly Correlated



Simple and Complex Abortion Dictionaries by Month, 2007-2017

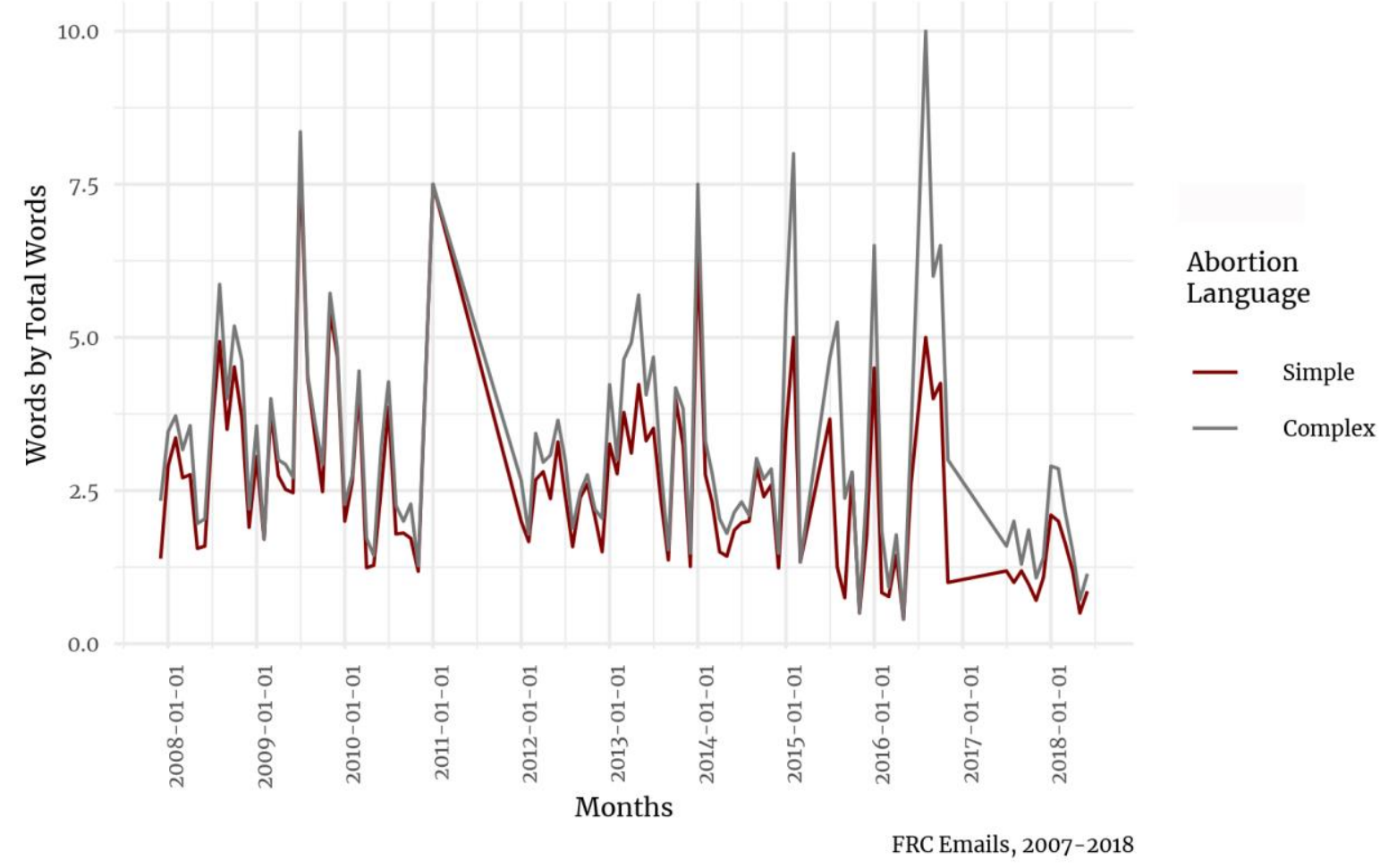


Figure A5 - Core Issue Agenda Email Communication by Month, 2007-2018
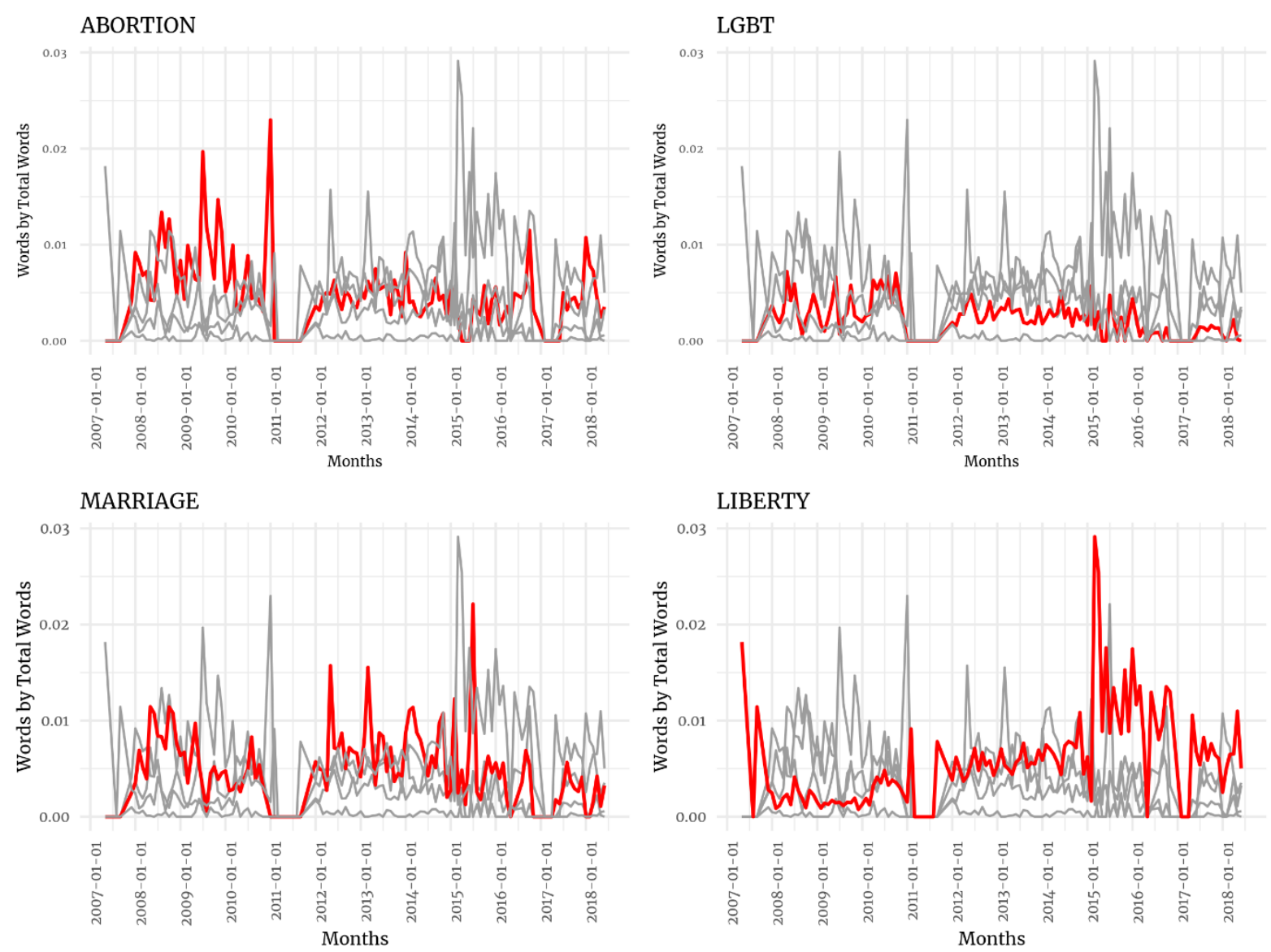
Figure A6 - Core Issue Agenda Press Release Communication by Month, 2013-2018 (Colored by Issue)
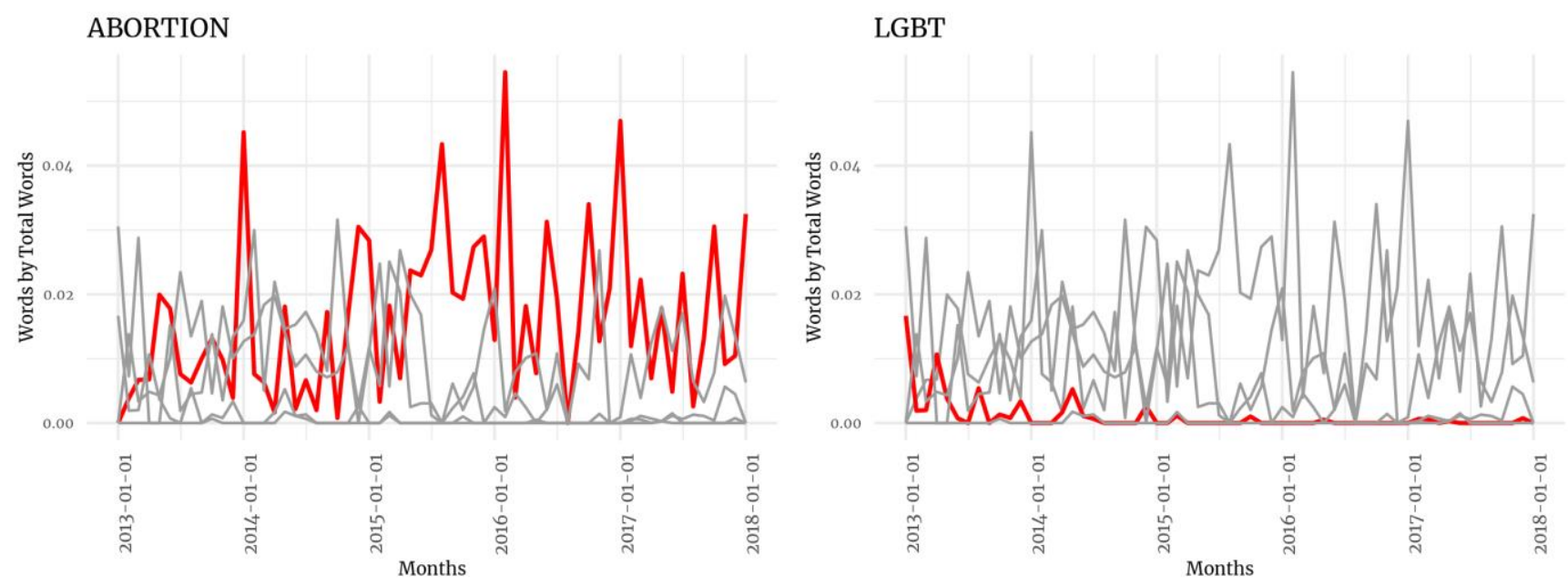

MARRIAGE

LIBERTY
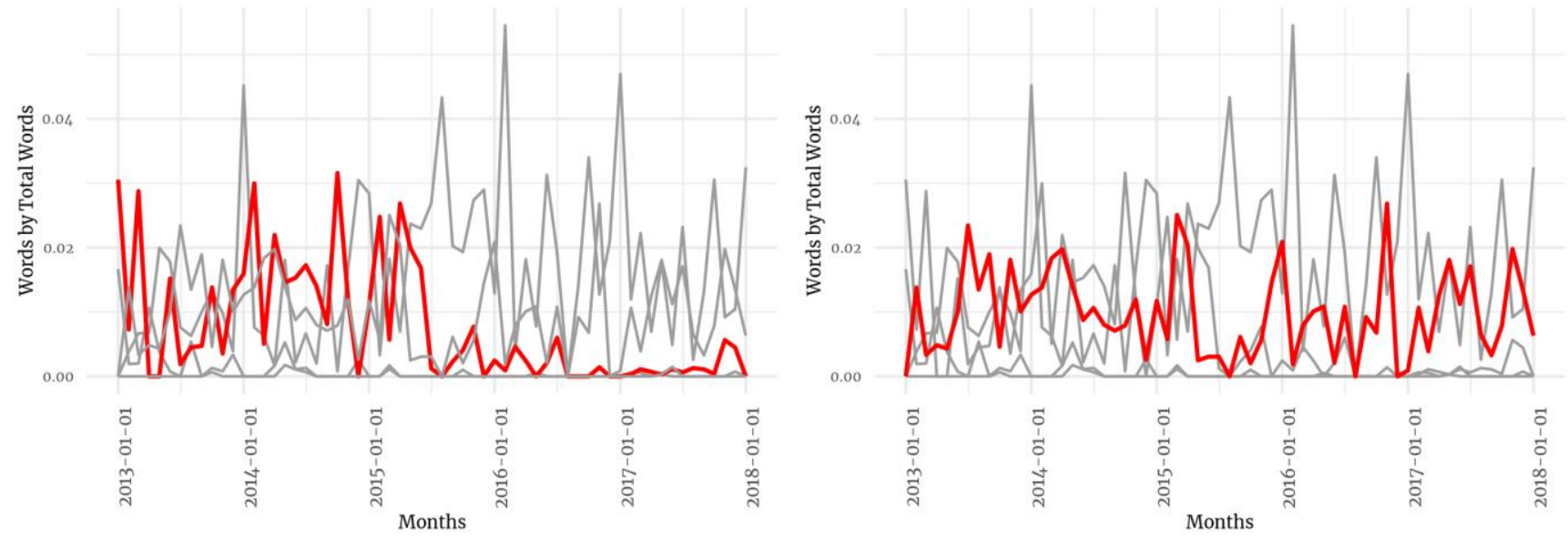
Figure A7 - How Email and Press Release Communication Tracks by Issue

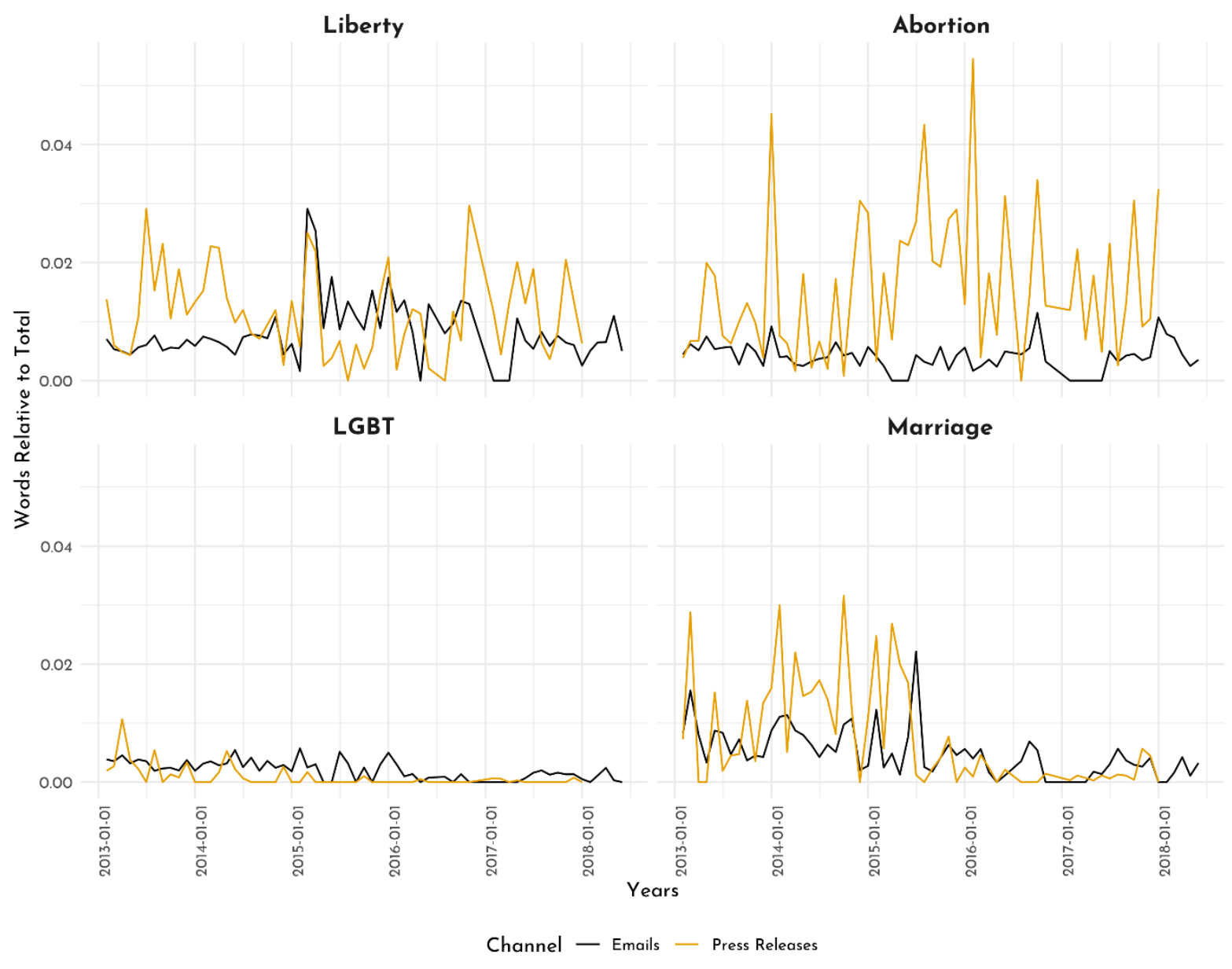


Figure A8 - Most LGBT Mentions Happened in the Context of Marriage (Emails)

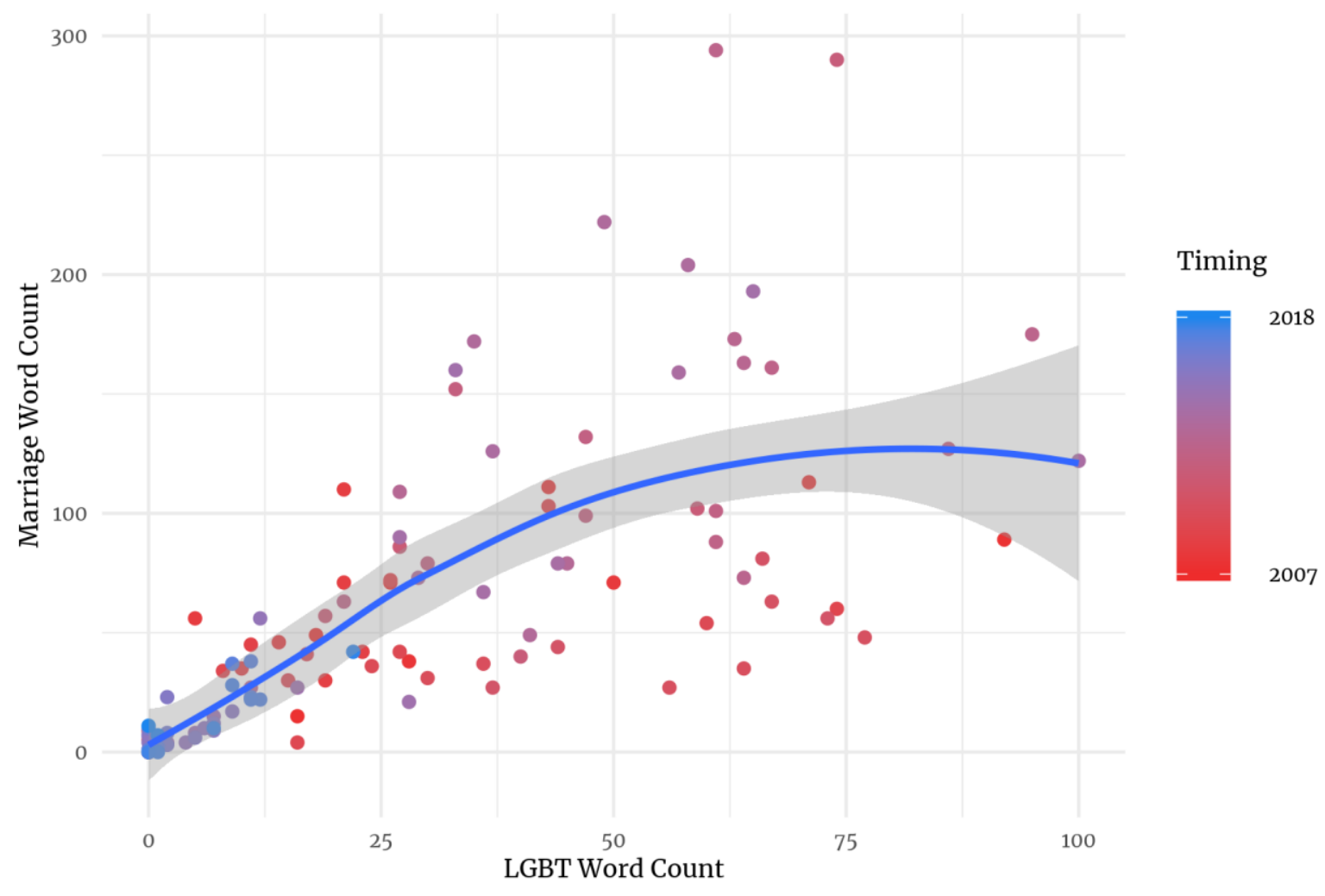


Figure A9 - Abortion and Marriage Are Not Often the Co-Focus of FRC Press Releases

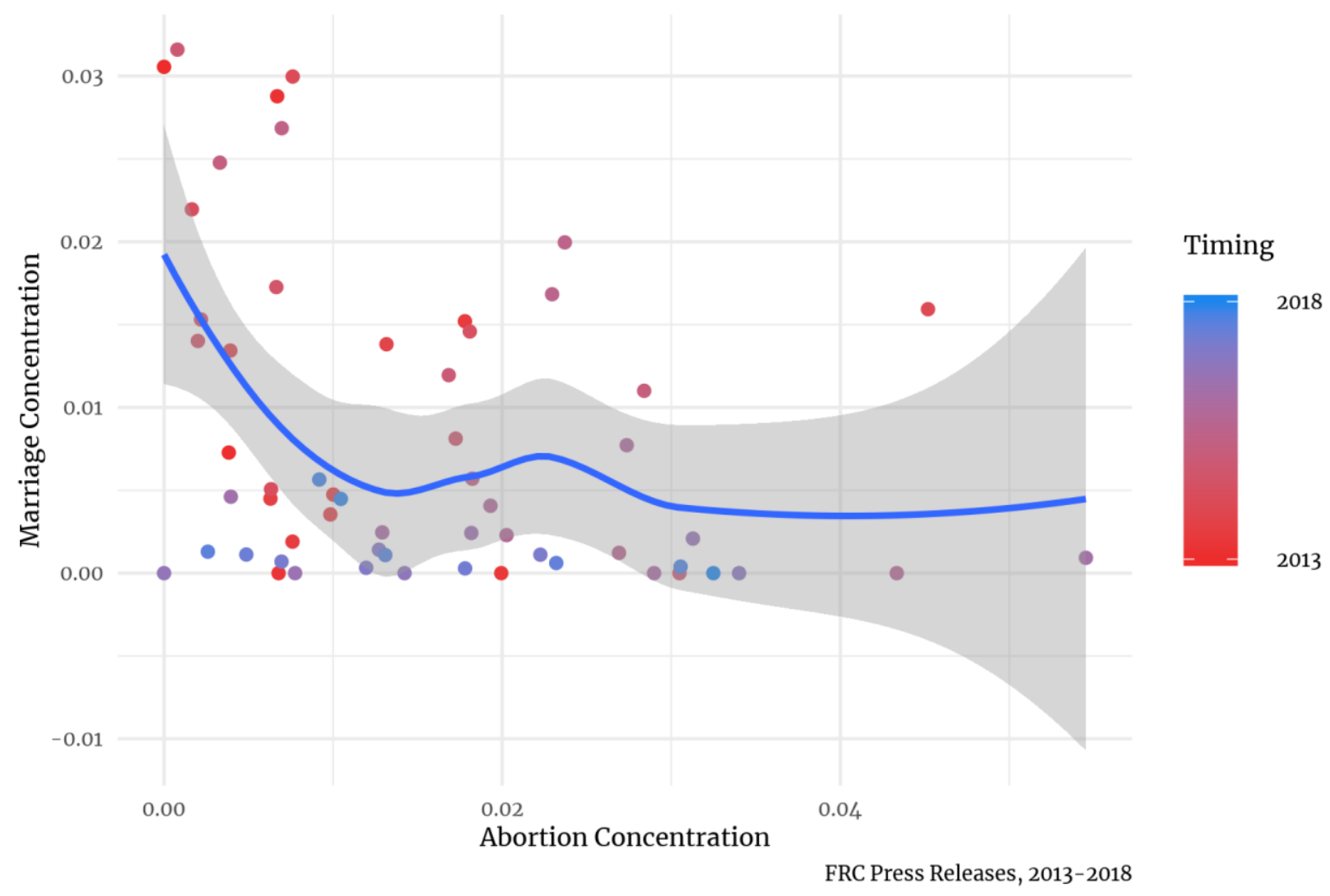


Figure A10 - Bills Mentioned More than Twice in FRC Emails

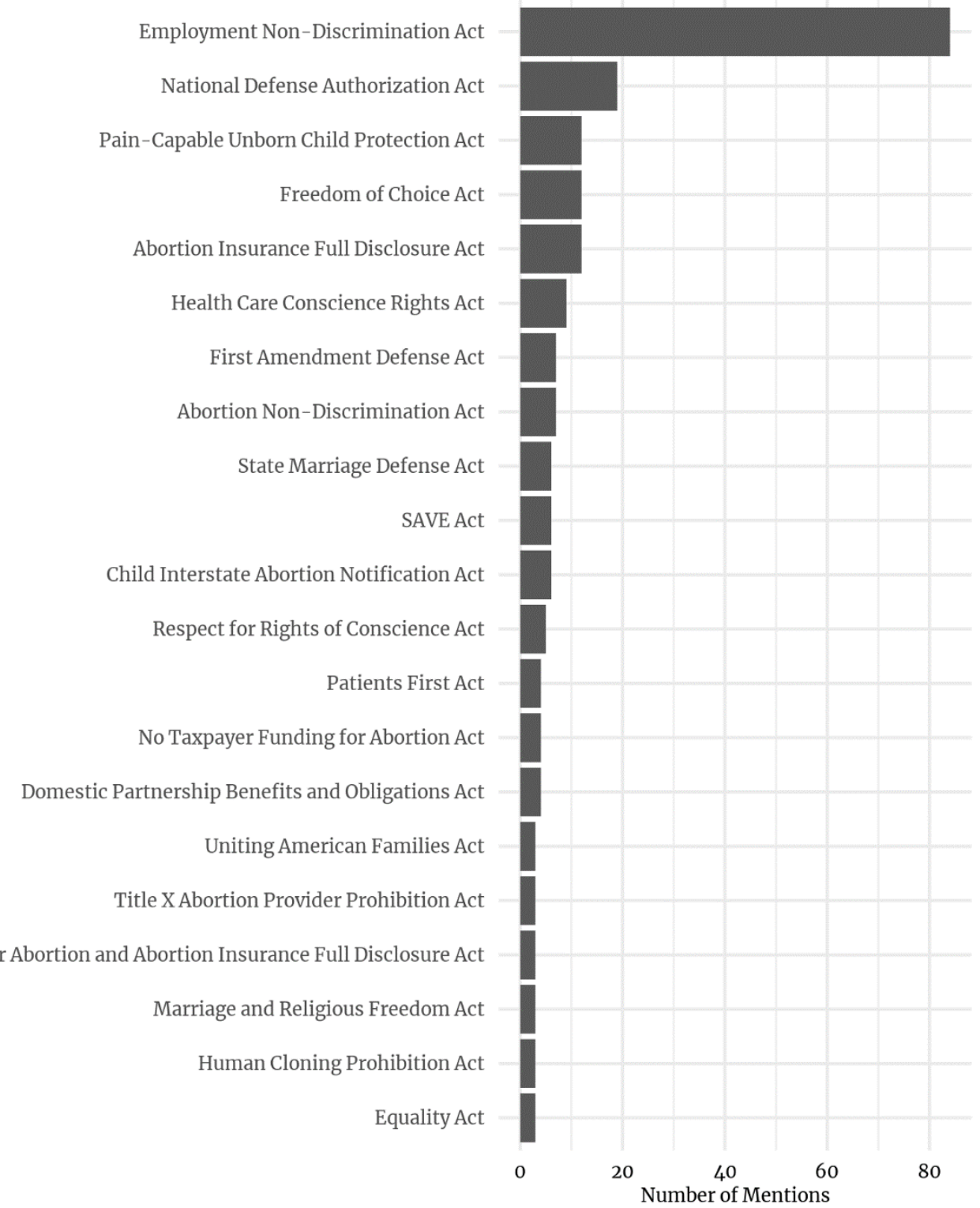


Figure A11 - There is a Slight Relationship Between Email Volume and Bill Mentions

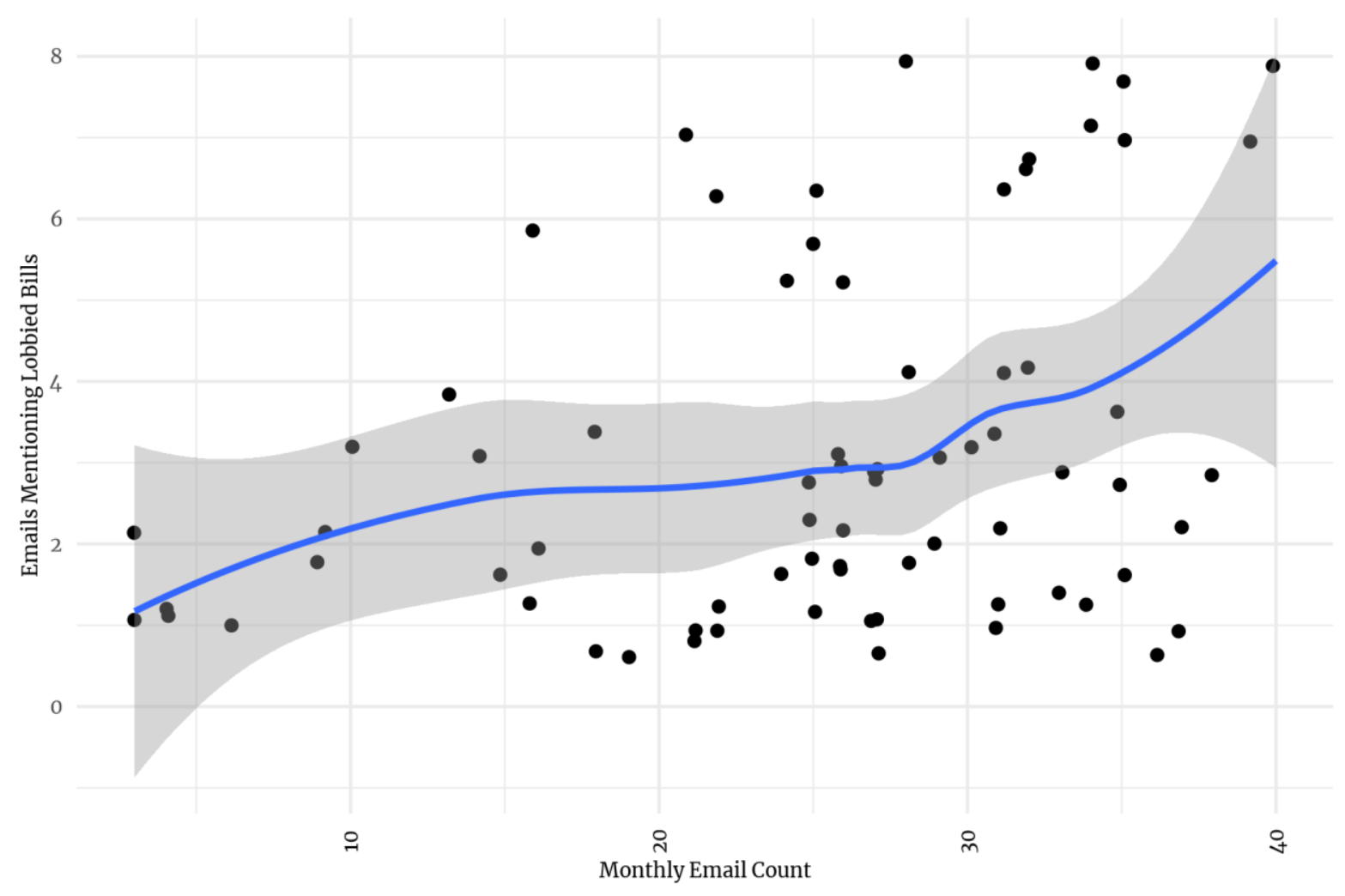

Note: Mentions $=1.82+.05 *$ emails in the month $(\mathrm{p}=.03)$ 